\title{
O SENTIDO SOCIAL DA REVOLUÇÃO PRAIEIRA.
}

\author{
(Ensaio de interpretação) $\left(^{\star}\right)$.
}
À memória do pernambucano Joaquim Nunes Machado, trucidado no Recife no dia 2 de fevereiro de 1849, em defesa da De- mocracia.
$*$
A memória do pernambucano Demócrito de Souza Filho, trucidado no Recife no dia 3 de março de 1945, em defesa da Democracia.

A província de Pernambuco mantinha ainda a tradição dos movimentos nativistas e republicanos dos princípios do século XIX. Persistia o fermento revolucionário que provocara as revoluções de 1817 e 1824, e que desabrochara, talvez, na guerra dos Mascates no alvorecer do século XVIII.

A "ardência natural dos pernambucanos" de que nos fala o padre Dias Martins (1) ou "o maligno vapor Pernambucano" do anônimo autor das Revoluções do Brasil (2) não morreram de todo. A agitação do período regencial repercutira de modo intenso em Pernambuco. Idéias separatistas fervilhavam, almejando separar o Norte do Sul, formando-se um novo império no setentrião (3). O projeto da regência da princesa Da. Januária num trono nordestino perdurara por muito tempo. Em pleno 1841, depois

(*). - O presente trabalho é a tese com que o Prof. Amaro Quintas se apresentou ao concurso para a Cadeita de História do Brasil do Colégio Estadual de Pernambuco, em 1946. Pela sua natureza de tese de concurso, teve divulgação restrita, pràticamente limitada àquêles que assistiram as provas do concurso. A Revista de História, em seu primeiro número (janeiro-março de 1950) teve oportunidade de divulgar, no Sul do Brasil, muitas das idéias desenvolvidas pelo professor pernambucano no trabalho que ora reproduz na integra. A exemplo do que tem feito com outros trabalhos de valor, já publicados no Brasil e no estrangeiro, acredita a Revista de História prestar assinalado serviço aos estudiosos da história brasileira reeditando tāo interessante e valioso estudo que, pela primeira vez, veio perscrutar *o "sentido social da revolução praieira". (Nota da Redação).

(1) - - Máttires Pernambucanos, pág. 259.

(2) . - Rev. do Inst. Hist. Geog. Pernambucano, n. ${ }^{0} 29$.

(3). - Ver: Alberto Rangel, Textos e Pretextos e No Rolar do Tempo... 
do golpe da maioridade, a imprensa ainda debatia essa grave e momentosa questão. O Correio do Norte (Col. Biblioteca Pública do Estado) na defesa dessa idéia, entra em choque com $O$ Nicoláu (Bibl. do Estado) e, principalmente, com A Ordem (Bibl. do Estado) que, em artigo no n. 3, de 30-10-1841, sob o título $O$ Clube da Rua do Hospício, diz:

"Consta-nos que sob a presidência do Snr. Peixoto de Brito se installara em a caza do Snr. Coronel José de Barros Falcão de Lacerda huma sociedade secreta que tem por fim dividir o Imperio do Brazil em dois : o do Sul e Norte competindo o Sceptro do $20^{\circ}$ à Serenissima Princeza Imperial a Senhora D. Januária".

E no n. ${ }^{\circ}$, de 4-12-1841, cita os nomes dos cabeças do movimento:

“...Os seos Costinha, Peixoto de Brito, o Jezuita, José Ignacio de Macedo, Roma e outros".

O fermento republicano transparece nesses projetos separatistas, muito embora enfeitado com roupagens monárquicas. Basta acentuar a figura de Antônio Borges da Fonseca, redator principal do Correio do Norte, o velho Repúblico, o intransigente defensor do sistema republicano. Num cenário agitado e inquieto, instável e turbulento como era o de Pernambuco, na primeira metade do século XIX, onde as idéias mais díspares se entrechocavam, fácil se tornava explodir uma revolução. O terreno era fértil. As mudanças políticas iam ser o pretexto para o desabrochar de movimentos impelidos por causas mais profundas.

A eterna rivalidade dos dois partidos, que viviam degladiando-se no Império, seria a aparente causa da rebelião da Praia.

Em verdade, porém, a luta tinha raízes mais sòlidamente fixadas.

Desde 19-9-1837, com o gabinete chefiado por Bernardo Pereira de Vasconcelos, imperava no panorama político nacional o reacionarismo mais completo. As fôrças da reação, que vinham dominando desde tempos longínquos, apresentavam-se, agora, com tôda a sua potencialidade. Em Pernambuco, começa o domínio da família Cavalcanti, representado pela ascenção de .Francisco do Rego Barros, o barão da Boa-Vista .

Era a oligarquia Rego Barros-Cavalcanti a iniciar um poderio dos mais absorventes e dominadores que o Brasil tem conhecido. O "gótico castelo" a que se refere o padre Miguel do Sacramento Lopes Gama, no seu 7 de Setembro, ia firmar-se com solidez na província, até que a Praieira viesse solapar-lhe os alicerces. Como disse o sr. Gilberto Freyre, era uma "espécie de Bastilha que foi preciso a Revolta Praieira para demolir" (4). Essa

(4). - Memórias do Um Cavalcanti, pág. 16. 
oligarquia, entretanto, não era um fato esporádico na nossa vida político-social; antes resultava da nossa defeituosa organização econômica e social. Se Pernambuco, em geral, e o Recife, em particular, se diferenciavam algum tanto da época de Koster ou de Tollenare, de Watterton ou de Maria Graham, nota-se, entretanto, muito do velho sistema patriarcal, eivado de aristocratismo, como que se transferindo da Casa-Grande para o Sobrado (5), baseado na posse da terra. Uma nobreza rural, possuidora de vastas extensões territoriais, exercendo um domínio completo no nosso meio político-econômico.

Quer em Gardner (6), quer em Kidder (7), quer em Hadfield (8), quer em Mansfield (9) - viajantes que nos visitaram nos meados do século XIX - nota-se o caráter patriarcal da nossa vida social, dominada, ainda, pelos terra-tenientes dos nossos engenhos. Disse Antônio Pedro de Figueiredo em O Progresso (10):

"Hoje mais de $3 / 4$ da população da nossa província se acha concentrada à beira do mar e numa profundeza de 10 a 15 léguas; mas, lá, quase com poucas exceções. tôdas as terras pertencem a um pequeno número de grandes proprietários que delas mal cultivam uma minima parte e recusam vender o resto. Dai vem que 200 ou 300.000 dos nossos concidadãos, mais porventura, vivem em terras de que podem ser despedidos dentro de poucas horas; humildes vassalos do proprietário, cujos. ódios, partido político, \& C., são obrigados a esposar.

Neste fato da grande propriedade territorial, nesses. novos Latifúndia, deparamos nós a base desta feudalidade que mantém diretamente, sob jugo terrivel, metade da população da província, e oprime a outra metade por meio de imenso poder que lhe dá esta massa de vassalos obedientes.

Reconhecemos que à existência desta feudalidade era que se devia attribuir a impunidade dos crimes, os escândalos das eleições, assim como o vagar com que caminha a nossa província na senda de tôda a espécie de progresso .

Reconhecemos que era ela que pela opressão em que mantém as populaçōes do interior, as obrigava a refluir para a capital da província, e abandonar a agricultura, para aumentar o número dos improdutivos e solicitadores de emprêgo.

Reconhecemos, numa palavra que a divisão do nosso solo em grandes propriedades era a fonte da maior parte dos nossos males".

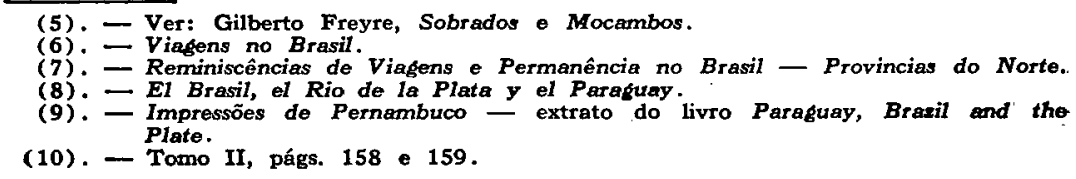


E ainda acrescenta:

"...A nossa província se acha agora naturalmente: dividida em 3 regiões. A $1 .^{a}$, occupada pelo fabrico do: açucar, estende-se da beira-mar até 15 ou 18 léguas para: o interior. A 2.a, estende-se até os extremos limites das. bacias do Capibaribe, do Ipojuca e do Una. A 3.a, enfim, comprehende os afluentes do S. Francisco. A falta $a b-$ soluta de estradas colloca esta ultima região inteiramente fora do movimento de produção e de exportação da provincia. A região central, arruinada pela destruição das mattas, e pela seca ocasionada por ella, não podedar lugar a uma produção certa, e alem disso está mui distante do nosso centro de commercio, e de troca, o. Recife. Resta, pois, a região do litoral, em que estão aglomerados os $3 / 4$ da população da provincia, e é a unica capaz, no estado actual, de produzir com abundância, e achar compradores para os seus produtos. Ora, esta região afora algumas porções arenosas da beira-mar, insalubres, improprias para a maior parte das culturas, se acha dividida em grandes propriedades, fragmentos das. antigas sesmarias. Desde o rio Abiay até o rio Persenunga, se não possuirdes bastante riqueza com que comprar ou arrendar um engenho, ou outra grande propriedade, não achareis uma polegada de terra cultivavel a comprar ou arrendar; e assim mesmo, os 9/10 das terras se acham incultos. Offerecer-vos-hão terras para cultivardes, mas sem garantia alguma, reservando-se o direito de vos despejar no outro dia, se assim convier. Aonde o homem não tem certeza de gozar dos fructos do seu trabalho; elle não trabalha, por isso o morador do engenho mal planta alguma roça em roda do seu mucambo, e, receiando a cada instante ser despejado, vive de almocrevar os açucares do dono da terra" (11).

A existência dessa "feudalidade", tão combatida pelos praieiros, contribuia imenso para tôda essa situação de desajustamento, queexistia na província, refletindo-se na insatisfação das massas, traduzida por uma surda hostilidade à aristocracia rural, e manifestando-se, no meio urbano, pela repulsa mais completa, ao elemento estrangeiro principalmente ao português que, tal como a nobreza. campesina, exercia nas cidades um domínio asfixiante e absoluto. A situação do pernambucano desprovido de riqueza era das mais angustiosas possível. Impossibilitado de voltar-se para a agricultura, porque esta se encontrava na mão dos grandes senhores deterras - no gótico castelo Rego Barros-Cavalcanti - encontrava a mesma dificuldade, se pretendia dedicar-se ao comércio, quase. todo êle em poder dos estrangeiros, ou para alguma atividade industrial, também monopolizada pelo elemento alienígena. Refe-

(11). - Ibidem, pág. 241. 
rindo-se à zona da mata, diz o arguto observador de $O$ Progresso (12):

"Esta região que se estende sobre todo o litoral da nossa provincia até uma profundidade de $10,12 \mathrm{e}$ às vezes 15 e 18 leguas para o interior, se acha, como se sabe, dividida em engenhos ou propriedades cuja dimensāo varia desde um quarto de legua quadrada até 2 e 3 , e até 4 e 5 leguas quadradas. Como a cultura da cana exige uma qualidade de terras particular, que se não encontra por toda a parte, segue-se dahi, que, afora as terras de cana, as matas que lhe são necessárias e as terras de que carece para os seus bois e a plantação da mandioca, indispensável ao alimento dos escravos, a mor parte dos engenhos possue vastas extensões de terrenos incultos, terrenos que seriam eminentemente próprios para a pequena cultura, e que, se fossem cultivados, bastariam para fornecer com abundancia farinha, feijão, milho, etc. a toda a população da provincia e das provincias vizinhas e até para a exportação. Ora, os proprietários se recusam a vender estes terrenos, e até a arrendá-los. Se possuirdes 30 ou 40 contos de reis, então podereis comprar um engenho; mas se sois pobre, e quizerdes comprar ou arrendar algumas geiras de terra, não achareis! $E^{\prime}$ isso o que faz que a população improdutiva das cidades, a classe dos solicitadores de empregos publicos se augmente todos os dias, que os crimes contra a propriedade se tornem mais frequentes e o paiz se empobreça de dia em dia, em consequencia do augmento do número dos consumidores, no entanto que o dos produtores permanece estacionário; ou ao menos não cresce senão em proporção muito mais lenta.

$O$ poder dos grandes proprietários do interior (e este poder é grande) tem por base o numero desses vassallos obedientes que elles manteem nas suas terras".

A Praieira foi mais uma resultante dêsse estado de desequilíbrio econômico-social, dessa insatisfação existente no meio da massa, do que mesmo um movimento provocado por causas meramente políticas. Nabuco sentiu bem êste aspecto da revolta. Diz-nos em Um Estadista do Império (13):

\footnotetext{
"Mais que um movimento politico, era assim um movimento social",
}

repetindo o que, antes, afirmara o velho Nabuco de Araújo:

"Não se trata ali somente de questões políticas; a estas questões políticas estão associadas questões sociais, e as questões sociais são de grande alcance, são de grande perigo".

(12). - Ibidem, pág. 217.

(13): - vol. I, pag. 75 . 
Havia no ambiente intelectual da Província um clima favorabilíssimo à expansão de idéias de reforma social. A agitação popular, correspondia a existência de uma elite intelectual propensa. à compreensão e propagação de princípios socialistas. A figura deVauthier, o engenheiro socialista contratado pelo govêrno provincial, merece realce particular pelo muito que influiu para o conhecimento das novas tendências do socialismo militante na Europa. No seu Diário Intimo (prefaciado e anotado pelo prof. Gilberto. Freyre) vê-se pela relação dos livros adquiridos e pelas revistas. assinadas e propagadas entre nós, como o técnico francês foi um elemento de difusão das preocupações reformadoras dos idealistas da primeira metade do século XIX. Há na sua lista de assinantes pernambucanos da Democratie, do Socialiste e da Phalange, vultos: de projeção cultural e política da espécie de Soares de Azevedo, Antônio Pedro de Figueiredo, Paula Batista e Antônio Borges da. Fonseca. Merece-nos, também, atenção a lista de livros à venda na casa de Manuel Figueiroa de Farias e na de Coutinho (14): Almanack Phalansterien, Les Enfants du Phalanstère, Notions de la Science Sociale, Petit Cours de Politique et d'Economie Sociale, Vie de Charles Fourier, Examen et Defense du Système de Fourier, Exposition abregée du Système de Fourier, Defense du Fourierisme, Debacle de la Politique. Há também no Diário Novo, n. ${ }^{\circ} 163$ de 29-7-1848, uma relação de livros à venda na loja de livros do Pátio do Colégio, n. ${ }^{\circ}$ 2, merecedora de referência: "Rossi, Curso de Economia Política, 1 vol., Catecismo de Economia Política por J. B. Say, Espírito da Economia Política por Ivan Galovine, Blanqui, História da Economia Política, edição de 1845, 2 vols.". Vê-se, por aí, como as preocupações dominantes no tempo se voltaram para os estudos econômicos e para as idéias de reforma social. Fourier, Proudhon, Owen, Saint-Simon e Luiz Blanc, isto é, todo o chamado socialismo utópico, vicejante na Europa de 1848, o socialismo utópico que fêz a revolução de fevereiro, na França, eram familiares. aos nossos intelectuais, especialmente depois da chegada de Vauthier, que, além de técnico hábil, interessado na solução de problemas importantes de engenharia, necessários ao progresso da Província, foi, sobretudo, um preocupado com as grandes questões de sentido social que nos assediavam. $O$ sr. Gilberto Freyre, em $U m$ Engenheiro Francês no Brasil, mostra-nos à saciedade a atuação de. Vauthier, pelejando com um alto interêsse humano, pela sorte dos. oprimidos e dos espoliados. Cita-nos o ilustre sociólogo pernambucano a reclamação dirigida pelo engenheiro gaulês ao desembargador Domingos Nunes Ramos, chefe de polícia interino, contra a. deficiente alimentação fornecida aos calcetas, o que vem compro- 
var ter sido Vauthier uma espécie daqueles técnicos de idéias gerais, de que nos fala o seu patrício Liautey, com uma visão mais humana e social dos problemas, do que outros técnicos de sua época. Diz-nos o prof. Arbousse Bastide:

"L'ingenieur a deviné, dès 1840 , que le problème fondamental du Brésil était d'ordre social".

Relações de amizade ligaram-no a Antônio Pedro de Figueiredo, "um dos primeiros socialistas brasileiros", e a sua colaboração na revista $O$ Progresso, encarregando-se da parte científica, revelanos todos os seus anseios de ordem social e as suas preocupações de soluções práticas das nossas questões. Diz-nos o prof. Gilberto Freyre:

"O socialista já com tendencias ao socialismo scientifico - que o outro, o simplesmente ideologico, ou paraphilosophico, não podia satisfazer uma intelligencia critica como a sua, nem um senso de realidade da agudeza do seu - chocou-se, no Brasil escravocrata e monocultor, as vezes de maneira violenta, com as condições ainda patriarchais de predominancia economica e politica dos particulares ricos, dos donos, as vezes ignorantes, de terras e de negros, sobre os demais elementos da população ou da organização social" (15).

A par de Vauthier, dois socialistas quase científicos se sobressaem pelo modo como encaram a situação dos nossos problemas fundamentais, em função do socialismo dominante no tempo: Antônio Pedro de Figueiredo, o Cousin Fusco e Abreu e Lima, o General das Massas. Os profs. Gilberto Freyre (16) e Olivio Montenegro (17) salientam a grande importância do primeiro como crítico social e revolucionário e acentuam a necessidade de um estudo mais acurado sôbre a sua interessante figura, que foi, nos meados do século passado, um dos mais lídimos representantes do ideal de reforma social, conjugado com o pensamento objetivo. $O$ sr. Oliveira Viana o classificaria, talvez, como "um idealista orgânico". Diz o autor de Casa Grander \& Senzala:

"Não se compreende que continue tâo na sombra, tão no escuro, tão dentro da alcunha que lhe deram os conterraneos (sempre tão apedrejadores dos prophetas) - a alcunha de "Cousin-fusco" - esse mulato que decerto não foi menos significativo como revolucionario intellectual do meio escravocrata do Nordeste e como critico da organização patriarchal então predominante,

(15). - Um Engenheiro Francês no Brasil, pág. 212.

(16). - Nordeste, Um Engenheiro Francês no Brasil."

(17). - Memórias do Ginásio Pernambucano. 
do que outros mulatos mais festejados: Natividade Saldanha, nos principios do seculo XIX, Tobias Barreto nos. fins" (18).

E, ainda acrescenta:

"Essa figura suggestiva de mulato intellectual da: primeira metade do seculo XIX pede um estudo à parte" (19) .

Afirma-nos, por sua vez, o autor de $O$ Romance Brasileiro:

"Foi Antônio Pedro de Figueireido dos primeiros em: Pernambuco, sinão o primeiro, a discutir e levar para um plano de idéias problemas que antes dêle eram ordinàriamente uma diversão da Retórica, e um pretexto para demagogia, como os relacionados com a literatura e com o sistema social e politico do Brasil" (20).

Nascido em Igaraçú de "paes desherdados de bens de fortuna", no dizer de Pereira da Costa (21) transferiu-se cêdo para o Recife, onde, no meio de inúmeras dificuldades, conseguiu adquirir, para a época, apreciável ilustração. Com 21 anos, traduzia o Curso de História da Filosofia de Cousin, ficando, desde então, conhecido pelos adversários, em alusão à sua qualidade de mestiço, pela alcunha de Cousin fusco, que, segundo o prof. Olívio Montenegro (22), devia doer-lhe menos que

"a indisciplina de gôsto e de cultura que via em. volta dêle, retardando da vida intelectual da sua terra. uma expressão de sentido nacional e humano".

Professor-adjunto do então Liceu, foi demitido, em virtude de sua oposição aos praieiros, por Chichorro da Gama, em 1846, em pleno domínio da Praia, e, finalmente, feito professor efetivo em. 1849. Celebrizou-se pela sua revista mensal $O$ Progresso, publicada regularmente de julho de 1846 até setembro de 1848, até, pois, às vésperas da Praieira (23) e depois pela publicação semanal intitulada $A$ Carteira, no Diário de Pernambuco (24) com o pseudônimo de Abdalah-el-Kratif.

Incompreendido por muitos e atacado, pelo facciosismo político, por vários, Antônio Pedro viu-se hostilizado e ridicularizado

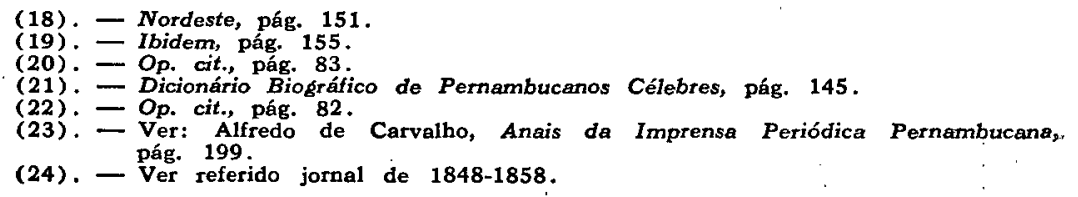


até quanto à sua capacidade intelectual. Vivendo numa época em que as paixões políticas fervilhavam e onde os pasquins e os jornalecos desenvolviam uma intensa campanha, apaixonada e virulenta de enaltecimento de uns e desmoralização de outros, o Cousin fusco sentiu, êle, que encarava as pugnas políticas dentro de um sentido mais digno e mais elevado, êle que fazia jornalismo com critério de doutrinação, de pregação de idéias, sem retaliações pessoais, nem disputas de aldeia, todo o travor da incompreensão dos seus contemporâneos. Enquantos os jornais baronistas o exaltavam, não por espírito de justiça, e sim por solidariedade política, as fôlhas da Praia atacavam-no rudemente. $O$ Postilhão, n. ${ }^{\circ} 13$ de 24-8-1846, procurando destacar-1he o valor cultural, diz:

"Foi demittido hum professor do Lycêo, o Figueiredo, e entrou em seu lugar huma sapiencia praieira ambulante, que graças a Deos, já não era de contrabando por ser Bahianno: e que succedeo, depois desta baldroca chichorratica? Esteve por muitos dias sem lente a aula de inglez, porque estava impedido não sei quem e não havia quem o substituisse, em outro tempo esse Figueiredo substituio muitas cadeiras estranhas à que elle professava no lyceo".

O mesmo vemos em $O$ Saquarema, n. 8 de 21-7-1846:

"O sr. Antonio Pedro de Figueiredo, o traductor da interessantissima Historia da Philosophia por Mr. Cousin, jovem de muitas esperanças e applicação, e que regia satisfatoriamente como substituto a cadeira de Geometria, tambem foi demetido, sem o menor erro de officio, sem a menor falta no referido dia 4 do corrente'.

Já $O$ Volcão acremente o hostiliza:

“...Aquelle tostado que vem a seu lado é o ridiculo Cousin fusco, filho do pardo Basilio lá de Iguarassú, onde sempre viveo de limpar a estribaria do Pai, e de pescar os seus ciriz e bodiões; mas em aqui chegando, quiz estudar, e indo fazer exame de geometria na Academia de Olinda, foi ali reprovado, o primo Xico Barão que sempre gostou, e teve muitas sympathias pela estupidez, o despachou para substituto do Lycêo desta Cidade na mesma faculdade, onde elle havia sido reprovado; é um mentiroso, e o maior caloteiro: não quer ser pardo, e chama a todos nós de canalha; é tão safado, que vindo aqui um seu irmão, disse a todos, que era seu creado quando só elle é o creado de boléa do primo Xico Barão" (25) .

(25)... - n. ${ }^{\circ}$, de 30-8-1847. 
E mais adiante, acusando-o de ignorante, acrescenta:

"...O Progresso que é escrito por J. S. e de queelle Cousin é apenas miseravel testa de ferro".

Em O Proletário (26) há também versinhos satìricamente maldosos, procurando historiar-lhe a vida e distinguindo-lhe a preocupação de ocultar as suas origens humildes. $A$ Tempestade (27), por sua vez, explora-lhe os requintes de vaidade de mulato janota, num artigo intitulado Desprezo a um litterato:

"Consta-nos que o jovem Cousin Fusco das mãos finas chegara-se a um correligionário e lhe dicera que precisava de algum dinheiro, e que este foi ter com a Commissão, a fim de ver se podia dar algum taco de toucinho. a esse ratinho; mas coitado! tal foi a sua infelicidade que a Commissão respondeo, que não havia quatro para sustentar o Iuxo de um pelintra, que gasta dous contos de reis no seo tola lette. Que ingratidão! Pois o homem não ha-de escrever entre frascos de agoa de colonia, e. da rainha de Ungria, para avivar-lhe a imaginação... Isto é que se chama menosprezo a um litterato".

Fala-nos, ainda, no rescender dos

"belos e suavissimos perfumes que tanto embalsamam o ar que se respira no toilette do nunca assas louvado Cousin fusco, desse fashionable didon brazileiro". (28).

Não são, todavia, os elogios dos seus partidários ou os ataques dos seus adversários - frutos todos êles das paixões violentas da época - que irão servir para caracterizar a essência da obra de Cousin fusco, ela própria acusada de não the pertencer e sim a um outro, indicado pelas iniciais de J. S., talvez, quem sabe, as de José Soares de Azevedo, colaborador d'O Progresso, grande professor e não menos notável crítico literário (29). A grandeza de sua obra encontra-se na sua atitude diante dos nossos problemas. Numa época em que predominava uma visão puramente utópica, impregnada de retórica e de divagações estéreis, é de admirar o modo como Figueiredo, nas páginas d'O Progresso, soube tão bem fazer crítica social, percebendo o verdadeiro. itinerário a seguir na solução das nossas questões. Vivenđo a agitação política de seu tempo, fêz, entretanto, jornalismo de idéias,.

(26). - n.o 3, de 28-8-1847.

(27) - n.0 5 , de 19-9-1847.

(28). - n. 4, de 14-9-1847.

(29): - Ver, sôbre Soares de Azevedo, o prof. Olívio Montenegro, op. cit., pág. 61. 
pairando, assim au dessus de la melée. Mesmo as violências que atingiam a sua dignidade de homem ou a sua situação financeira, encontravam, de sua parte, uma reação muito reduzida e serena. A sua demissão, em 1846, de professor do Liceu, não o afastou da velha trilha do comentário sóbrio e desapaixonado (30). Mas, ninguém percebeu tão bem, naquela fase de paixões destemperadas, com tanta clareza e tanta argúcia, os verdadeiros males que pairavam sôbre a nossa estrutura político-econômica. Discípulo dos socialistas utópicos da primeira metade do século XIX, soube, todavia, dar um cunho pessoal às suas idéias e, nas páginas d'O Progresso, deixar tôda uma concepção que se encontra adiantada de um século. Diz-nos Alfredo de Carvalho (31):

"E na ocasião abraçava com entusiasmo as doutrinas de Theodoro Jouffroy, às quais soubera dar um cunho individual, modificando-as em parte ao influxo das theorias economicas de Saint Simon, Owen e Fourier, creando assim uma orientação propria e original, fructo notabilissimo da evolução dum espirito naquela epoca e no "nosso acanhado meio provinciano".

Admirador entusiasta de Fourier, a ponto de chamar-lhe "o maior gênio do século" (32), foi-lhe, entretanto, mais além, chegando mesmo a sentir a separação e o antagonismo das classes:

"O sofrimento social, proveniente da incoherencia das relações que ora existem entre os homens, como productores, distribuidores e consumidores, continua a manifestar-se claramente, nas partes mais ricas e civilizadas da Europa, por uma divisão cada vez mais profunda, entre as classes que gozam ociosas e as que trabalham quebrantadas pela miseria" (33) .

Não ficou adstrito aos socialistas franceses; nas páginas de sua revista, sente-se como o mulato socialista era conhecedor do desenvolvimento do socialismo nos outros lugares, sobretudo entre os povos de origem saxônica (norte-americanos, inglêses e alemães). Cita-nos o simbolismo de uma das questões agitadas pelos comunistas alemães nos seus clubes na Suiça:

"Que nos resta a fazer? Esperar melhores tempos. - Quais são êstes tempos? Aquelles em que as nossas rosas florescem. - Que rosas, brancas? Não; vermelhas".

(30). - Ver o Progresso, agôsto de 1846

(31). - Estudos Pernambucanos, pág. 72.

(32). - O Progresso, tomo III, pág. 6 .

(33). - Tomo I, pág. 146. 
Para êle os fenômenos da supra-estrutura tinham uma importância muito reduzida. Pergunta:

\author{
"Que são as reformas políticas sem as reformas so- \\ ciais? Uma mascara e nada mais".
}

Causa-nos admiração como, numa época tão estreitamente ligada aos principios do liberalismo da Revolução francesa tivesse - Cousin fusco avançado tão prodigiosamente no pensamento político-social, a ponto de podermos situá-lo como um verdadeiro precursor da democracia social dos nossos dias de democracia planificada. Eis como êle encara a atitude do Estado, em frente aos fenômenos econômicos:

"Nós tambem pretendemos, é que o governo, como representante da sociedade inteira, intervenha nos phenomenos da producção, distribuição e consumo, para regula-los e substituir pouco e pouco uma ordem fraternal ao desgraçado estado de guerra que ora reina nestas importantes manifestações da atividade humana" (34).

E, mais adiante, o seu brado de revolta:

"De facto, que papel podem representar a Igualdade, a Fraternidade e a Liberdade nas nossas sociedades modernas? Que he a Igualdade onde pequeno numero de privilegiados gasta na ociosidade o produto do trabalho de muitos milhares de seus irmãos? Que he a Fraiernidade num gremio social que deificou o egoismo sob todas as formas, e escreveu na sua tandeira esta immoral divisa: chacun pour soi; chacun chez soi? Que he que pode significar o vocabulo Liberdade numa sociedade em que as massas dependem de um pequeno numero de homens que, de facto, exercem sobre ellas un direito de vida e de morte, por mercê d'o capital! Até hoje, a grande formula humanitaria, proclamada pelos legisladores de 1791, não ha sido senão uma mentira odiosa" (35).

A preocupação fundamental do genial mestiço foi o nosso problema social. A visão da nossa sociedade escravocrata e monocultora, firmada na grande propriedade territorial, impressionou-o fortemente. Viu no domínio dos senhores da Casa-Grande, já se transferindo para os Sobrados, na "feudalidade" da nobreza rural, o maior entrave ao nosso progresso e o maior obstáculo ao desabrochar de uma classe média - pela existência da qual tanto se debateu - capaz de provocar o aparecimento daquilo que, até então, tinha sido um mito: a existência de uma opinião pública. Viu mais

(34). - O Progresso, tomo 3, pag. 86 .

(35): - Tomo III, págs. 6 e 7 . 
longe do que os outros; o mal não estava sòmente nos Cavalcantis e sim na defeituosa organização social. O despotismo exercido pela aristocracia campesina não advinha ùnicamente da oligarquia Rego Barros-Cavalcanti, mas sim do latifúndio, gerador de um regime arbitrário, de mandões violentos e tirânicos, desrespeitadores até das determinações das autoridades:

"este regime arbitrario provem da organização actual da propriedade no interior... (36) matai o despotismo na pessoa da grande propriedade territorial" (37).

E não carrega nas tintas ao pintar o quadro da situação da nossa sociedade, eivada de patriarcalismo:

“...Entre nós, a autoridade e o individuo se acham em circunstancias totalmente differentes. A maior parte do territorio da nossa provincia está dividio em grandes propriedades, fragmentos das antigas sesmarias, das quaes mui poucos ham sido subdivididos. O proprietario ou rendeiro occupa uma parte dellas, e abandona, mediante pequena paga, o direito de permanecer n'outra e de cultiva-la, a cem, duzentas e algumas vezes a quatrocentas familias de pardos ou pretos livres, dos quaes elle se torna protetor natural; mas delles tambem exige obediencia absoluta, e sobre elles exerce o mais completo despotismo. Dahi resulta que as garantias da lei não são para estes malaventurados, que entretanto compõem a maior parte da população da provincia, mas para estes proprietarios, dos quaes 3 ou 4 , reunidos pelos laços de sangue, da amizade ou da ambição, bastam para aniquilar, numa vasta extensão de terreno, as forças e influencia do governo. Assim, estes novos barões feudais, quando suas propriedades se acham muito distantes da capital da provincia, vivem numa independencia quasi completa" (38).

E brada, cheio de incontida revolta:

"Chora, Pernambuco, chora. Estes senhores de hoje são teus irmãos; mas que te importa que os que vivem dos teus suores tenham bebido ao nascer, as aguas do Tejo e do Douro, ou as dos rios da terra de Santa Cruz?

"O Capital defrauda desapiedadamente o trabalho" foi um slogan do Figueiredo tão atual que lembra o pensamento de um marxista militante, transplantado para o Recife de 1847. Há um traço

(36). - Tomo II, pág. 67.

(37). - Ibidem, pág. 158.

(38). - Tomo I, pág. 208. 
bem marcante na sua obra de observação e de crítica sociais: o sentido positivo de sua pregação. Abundam, na sua revista, as soluções concretas, indicativas de um temperamento objetivo, propenso à crítica social realista. Impôsto territorial visando a acabar com a grande propriedade, nacionalização do comércio, impôsto sôbre rendimentos, proteção às terras assoladas pela sêca, organização de comissões científicas para o estudo dêsse fenômeno climático, tendo em vista a sua extinção, criação de um banco popular para destruir a usura, diminuição dos abusos da centralização, tudo isso, foi minuciosamente estudado e analisado pelo O Progresso, com o intuito de tornar-se um fato concreto a nobre esperança do mulato de Igaraçú:

"O mundo não será para sempre o patrimonio de alguns privilegiados; ao passo que a imensa maioria se estorce sob as angustias da miseria".

E o seu sonho, seria o sonho de todos os socialistas da terra, dos antigos e dos novos, condensado no pensamento que retirou da revista $N$ ew America e que colocou, como manchette, na sua:

"And in a generation all would be freeholders, and the landlord breed extinct, except, perhapss, a stuffed specimen ortwo in the museums'.

Outro que encheu a nossa vida político-social com idéias reformadoras foi o general Abreu e Lima, cuja tradição remontava ao fuzilamento do padre Roma e às campanhas de Bolivar. Diretor do Diário Novo foi, entretanto, nas páginas de $A$ Barca de $S$. Pedro que o General das Massas teve oportunidade de expandir a sua concepção de um ideal de reforma social, sem falar nos seus vários livros publicados. "Somos na verdade socialistas", é o seu brado que encontramos em $A$ Barca de S. Pedro, n. ${ }^{\circ}$ 20. Menos avançado que o Cousin fusco, preconiza a tese de que

"o capital e o tratalho se harmonizem, porque disto e somente disto depende a ordem, a paz, a permanencia, a organização democratica da sociedade" (39).

Todavia, mais adiante, clama pela necessidade de resolver-se

"o grande debate entre a Economia official, que exclusivamente se occupa da creação das riquezas e a Economia social, que se entretem de sua distribuição".

Precusor da teoria da luta de classes (40), foi, ainda, um antevisor da influência dos fenômenos da infra-estrutura:

(39). - A Barca de S. Pedro, n. 19.

(40). - Ver Gilberto Freyre, Sobrados e Mocambos, pág. 14; Nordeste, pág. 156. 


\begin{abstract}
"Estes fenomenos economicos não podem ficar no esquecimento sem que os males da sociedade em que vivemos se agravem todos os dias; cumpre portanto prevenil-os com tempo" (41).
\end{abstract}

Espírito também voltado para os assuntos objetivos, dêle encontramos no Diário Novo e em $A$ Barca de S. Pedro, estudbs de compreensão de nossos problemas. São inúmeros os seus artigos ¿doutrinários e de crítica: "A Centralização do Poder ["Essa centralização no Rio de Janeiro é uma máquina de revoluções (42)], sôbre nacionalização do comércio (43), sôbre recrutamento (44), $O$ triunfo das idéias socialistas (45), $A$ colonização que convém ao Brasil (46) e até sôbre o uso da banana e da batata doce, como substitutos do pão (47). Embora êsse último trabalho venha sem assinatura e seja uma reprodução do Diário Novo, conseguimos encontrar no diário de Abreu e Lima (48) uma referência do General da Massas, como sendo de sua autoria o referido artigo. Se em 1835, no seu Bosquejo Histótico, Político e Literário do Brasit, como acentua o prof. Gilberto Freyre, já dividia a nossa sociedade em duas classes rivais - "pessoas livres e pessoas escravas", antecipando-se, assim, à tese defendida por Marx e Engels no seu célebre Manifesto Comunista, da existência de uma luta de classes, em 1852 escrevia o primeiro trabalho no Brasil intitulado $O$ Socialismo, tratando, naquela época afastada, de um tema não muito familiar mesmo às elites intelectuais. Quanto ao bom sucesso do livro e à acolhida tida no meio pernambucano, encontramos, em um trecho de uma carta de Abreu e Lima a Zacarias de Góis e Vasconcellos, agradecendo-lhe a remessa de $O$ Poder Moderador, dêste último, e datada de 15-12-1862, a seguinte declaração:

"Igualmente achará V. E. outro exemplar de uma obra minha. - O Socialismo - publicada em 1855, deqe. talvez V. E. não tenha a menor noticia pqe. aqui mesmo esgotou-se a edição. He uma obra purame. social, emqe. tratei de esboçar o progresso humano desde a queda até o gráo de rehabilitação emqe. nos achamos' (49).

Nesse tempo, que se estende dos pródomos da Praieira até a sua .repercussão, encontra-se uma imprensa fértil em tendências refor-

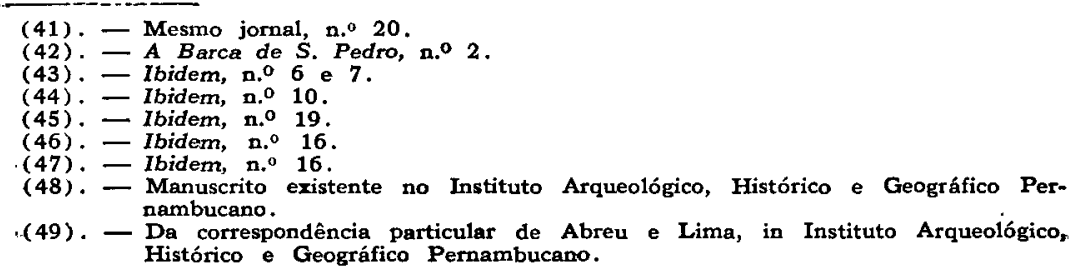


madoras. 'Tendências que vão de uma órientação republicana e federativa a imprecisas e confusas manifestações de reivindicações da massa. Borges da Fonseca, com os seus jornais, como $O$ Nazareno, $O$ Tribuno e depois $A$ Revolução de Novembro, além dos inúmeros pasquins que publicou na sua agitada vida de eterno redresseur des torts, João de Barros Falcão de Albuquerque Maranhão (50), Afonso de Albuquerque Mello (51), Ignacio Bento de Loyolla (52) e Romualdo Alves de Oliveira (53), mostram bem a trepidação de uma fase histórica, em que se sentem os anseios de uma mutação completa nos quadros da sociedade, uma preocupação de revisão de sistema e processos sociais e econômicos.

Idéias de reforma social, umas inteiramente impregnadas de socialismo utópico, outras, avançadas para o tempo, de verdadeiro socialismo quase-científico, se infiltravam pelo meio pernambucano, deixando um lastro de reivindicações sociais que iria, encontrando pleno apôio nas aspirações, ainda imprecisas, da massa, agitar fortemente a Província.

Desde 1837, como adiante vimos, o reacionarismo tinha-se apossado do poder, continuando uma cadeia, algumas vêzes ligeiramente interrompida, mas sempre ressurgindo na nossa História, dirigida para a conquista das posições de mando. Em Pernambuco, o gabinete de 19-9-1837 trouxera o domínio da oligarquia Cavalcanti; que iria, ao lado de empreendimentos notáveis para o desenvolvimento da Província, trazer um monopólio familiar, intensamente prejudicial, sobretudo pela fraqueza do barão da Boa-Vista, incapaz de coibir os desmandos de seus parentes, vários dêles abusando de sua posição para contrabandear africanos, roubar escravos, fazer cédulas falsas e até cometer assassínios. Delineava-se o quadro pintado, realisticamente, por Antônio Pedro Figueiredo, em $O$ Progresso, do domínio abusivo da aristocracia rural, da nobreza territorial, possuidora de largos tratos de terra e exercendo a sua fôrça de classe dominadora, por intermédio de presidentes de províncias retirados de seu seio ou solidários com ela. O Cousin fusco já denunciara o mal e falara

"na possibilidade de ter (a provincia) um presidente que gozasse de certa liberdade de ação, e se não

(50). - O Grito da Pátria, O Apóstolo do Norte, O Brasileiro.

(51). - A Reforma, A Mentira A Verdade, A Revoluçäo de Novembro.

(52). - A Voz do Brasil, O Conciliador, O Eco Pernambucano e o Jornal do Com-

(53). - $O$ Artista Pernambucano, $O$ Brado do Povo. 
visse coagido na nomeação dos empregos publicos pela aristocracia" (54).

E, muito embora a sua aproximação política com Francisco do Rego Barros, reconhecera que os barões de Suassuna e Boa Vista tinham, nas suas gestões, atraído a si "a maior parte dos negociantes e grandes proprietários" (55). Paes Barreto, Rego Barros, Cavalcanti formavam um grande grupo unificado pelos laços de família e pela solidariedade de classe. Alguém fixara o panorama com rara felicidade:

\author{
"Quem viver em Pernambuco \\ Deve estar desenganado, \\ Que ou ha de ser Cavalcanti, \\ Ou ha de ser cavalgado" (56).
}

O drama da Província ia de fato ser o antagonismo entre Cavalcantis e cavalgados. Entre opressores e oprimidos. Entre possuidores de terras, fazendo e desfazendo nos negócios políticos è econômicos e deserdados dos bens de fortuna, desprovidos de recursos e situados numa completa situação de inferioridade (57). Espetáculo perfeito da luta de classes que iria explodir, com impetuosidade, na revolta da Praia. O padre-mestre Lopes Gama, com - seu senso arguto de observação e seus modos desabusados de panfletário, notara

\footnotetext{
(54). - Tomo I, pág. 210.

(55) - Tomo I pág. 206

(56). - $O$ Sete de Setembro, n. ${ }^{\circ} 11$ de 14 de outubro de 1845 , reproduz essa quadrinha sem apresentar-lhe o autor. Pereira da Costa, Dicionário Biográfico de Pernambucanos Célebres, identifica-o na pessoa do Dr. Jerônimo Vilela Tavares. Clóvis Bevilaqua, além de dar-lhe a paternidade da espirituosa quadra, ainda o apresenta como autor de uma outra que não teve a mesma divulgação:

"Os leöes venezianos

Têm as azas na dorsal

Os leôes de Carauna

Gravidade natural".

(História da Faculdade de Direito do Recife, vol. II, pág. 24).

(57). - Naburo de Araújo nos apresenta uma visão admirável dêsse conflito ne zona rural: "Foi tal o terror que se incutiu na população que os moradores dos engenhos - que desde tempos imemoriais têm considerado aos senhores de tais propriedades como seus sustentáculos e protectores, que hão sempre tido para com estes um justo respeito reverencial, como para aquelles que lhes dão terras para lavrar e caça para comer; que não pagam por isso a menor retribuição pecuniárią, o menor serviço pessoal, a menor prestação em generos, nem fazem o menor beneficio ás terras pela plantação de arvores fructiferas ou de construção - que esses homens, dizemos nós que se uniam aos senhores de engenho pela força do habito, pela influencia dos costumes antigos, pelos laços da gratidão, antes quizessem votar com a policia que os aterrava do que com os seus patronos naturaes que os sustentavam; e como os senhores de engenho pelo legitimo uso de sua propriedade têm o direito de expellir de suas terras os moradores que lhes nẩo agradam, a policia actual, vivendo sempre de illusões e traficancias, não duvidou propalar por seus agentes que tal direito não existia, e que ella interviria para o fazer cessar e formaria processos aos senhores de engenho que delle lançassem mão para conseguir seus fins e impor sobre a opinião. A policia destruiu assim a justa relação que existia entre os proprietários dos engenhos e os seus moradores, alterou os costumes, e só produziu males, porque taes homens não podem mais ficar nos engenhos, que atraiçoaram de certo modo". (As eleiçöes para senadores, pág. IX).
} 


\begin{abstract}
"que muitos sujeitos, que nunca ninguem conheceu por parentes della, derão por miseravel adulação em assignar-se Cavalcantis: e note-se mais, que entre estes dizem, que há sua consideravel differença; porque uns são Cavalcantis com $i$; e outros Cavalcantes com $e$; que os primeiros são fidalgos de alto cothurno, e os segundos de meia tigella" (58).
\end{abstract}

Em A Tempestade (59) há uma referência humorística ao prestígio do nome Cavalcanti:

“Consta-nos que o sr. Antonio Joaquim de Mello verificando ser também descendente dos nobres de Florenca mudou o nome para Antônio Joaquim de Mello Hollanda Cavalcanti Rego Barros de Albuquerque Maranhão" (60).

Como já notara Joaquim Nabuco (61) além do aspecto de rebeldia contra a opressão do elemento territorial, havia, também, na Praieira, a repulsa ao estrangeiro, controlador da nossa atividade comercial (62). O mulato socialista de $O$ Progresso acentuara, também, essa situação:

"O commercio de grosso-trato exige grandes capitaes e por isso se acha nas mãos dos capitalistas europeus. Quanto ao commercio a retalho, que entre nós tem por base o credito, e poderá offerecer preciosas saidas a grande numero de nossos concidadãos, ora reduzidos ao papel de solicitadores de empregos publicos, está sujeito ao mais exclusivo monopólio de fato dos antigos colonizadores do paiz" (63).

A antipatia ao português, monopolizador do nosso comércio, estendia-se ao estrangeiro, em geral, pois não eram sòmente os lusos que concorriam com o nativo na profissão mercantil, e essa concorrência foi com o tempo ampliando-se a várias atividades. $\mathbf{E}$, assim, a hostilidade não era só em relação ao lusitano, mas igual-

\footnotetext{
(58). - O Sete de Setembro, mesmo número.

(59): - N. 5 , de 19-9-1847.

(60). - Maximiano Lopes Machado, no seu Ouadro da Revolta Praieira na Pro Víncia da Parahyba, pág. 48, nota, refere-se, também, a um Delfino Soares, que "por occasião da influencia legitima de Pernambuco crismou-se $-\mathrm{Ca}$ valcanti d'Albuquerque -; e posteriormente inculcando-se de - fidalgo, e rico - na Parahyba, tornou-se o epigramma vivo dessa familia, por ter em i patentes as attestados da sua nobreza".

(61). - Um Estadista do Império, tomo I, pág. '57.

(62): - A reação aos dois elementos opressores transparece no côro do Hino Liberal "A Liberdade vacilla:

As armas Pernambucanos

Corramos a combater

Guabirús e Lusitanos"

(Coleção da Biblioteca Pública do Estado de Pernambuco)

(63). - O Progresso, tomo II, pág. 240
} 
mente ao europeu vindo para prejudicar o filho da terra (64). Um nacionalismo exagerado, uma verdadeira manifestação de xenofobia, surgiu, impelida pela ação de jornais como $A$ Voz do Brasil e O Nazareno. Eis o panorama esboçado por Borges da Fonseca:

"Temos sim nossa agricultura acabrunhada per o gravame de orrorozos tributos; temos o comersio vasilante e sem fé, expostos todos ao caprixo do mais forte, e do bancarroteiro; temos as artes, q'iam nasendo mortas ao nasedouro, por esa barbara concurrensia estranjeira, de modo q'o estranjeiro já nos importa telha, tijolo e cal, de modo q'nossos sapateiros, alfaiates, ferreiros \& C., já não podem tirar o mesquinho lucro da mão d'obra, porq'o estranjeiro enxe o mercado de sapatos \& C., mais barato" (65). nunciava:

Por sua vez, Inácio Bento de Loyolla, pela Voz do Brasil, de-

"Não menos de seis mil cazas de commercio a retaIho se achão em Pernambuco, e todas ellas de estrangeiros: assim - logistas, quitandeiros, taberneiros, armazeneiros, trapixeiros, assucareiros, padeiros, cazas de rópa feita, de calsado, funileiros, tanueiros \& tudo he estrangeiro. Cada huma dessas cazas tem 3 e 4 caxeiros todos portuguezes; calculemos porem a dois, e teremos doze mil caxeiros, com seis mil patrões, dezoito mil portuguezes que nos excluem do commercio. Os fundos com que elles commerciam são nominaes, que elles todas as compras fazem aos negociantes de grosso trato a prazos. $\mathrm{Si}$ pois esse direito fosse excluzivo dos brasileiros, direito que se guarda religiosamente nas outras nações, não estarião acomodados dezoito mil pernambucanos? E notai que até hoje cargeiros são portuguezes" (66).

Em outro número, afirmava:

"Existem na rua da Praia para mais de 120 marinheiros no commercio de carne secca, e apenas 3 brazileiros" (67).

A irritação popular transparecia nas quadrinhas agressivas:

(64). - Ver: Gilberto Freyre, Um Engenheiro Francês no Brasil, pág. 37.

(65): - O Nazareno, n. $0^{36}$, de 25-11-1843. Chama atenção nos escritos de Borges da Fonseca a extravagância de sua ortografia. Já no n.o 1 de $O$ Repúblico, de 2-10-1830 ( afirmava êle não seguir a "ortografia filosófica ou da pro nunciação" e que "por ora tem desprezado o sedilho", o que levou o sr. Hélio Vianna a dizer que "realmente, pode Borges da Fonseca ser considerado um dos mais arrojados precursores das ortografias confusionistas às vêzes propostas entre nós". (Contribuição à História da Imprensa Brasileira, (1812-1869), pág. 541).

(66). - N. ${ }^{\circ} 13$ de 29-1-1848.

(67). - N.0 20 de 17-3-1848. 
"Corja vil de vis marotos

Amigos das borracheiras

Darvos-hemos a resposta

Nas pontas das lambedeiras" (68).

E já em plena revolta Praieira:

"Cabra bixo do Brasil

Nascido na casa forte,

Já não teme a luza gente

Pois se leva a xicote" (69) :

No Maccabeo encontramos uma análise completa de nossa sițuação econômico-social:

"E' extraordinaria a influencia do capital sobre a produção, e a tendencia que tem elle para escravisar as outras forcas produtivas. E' este um facto da sciencia. economica que não pode ser posta em duvida pörqué' um axioma.

Desta guiza a unica classe Brasileira, que toma parte activa na producção, e que tem o seu quinhão na distribuição das riquezas a classe dos proprietarios de terras, tendo precisão de capitaes para desenvolver a industria agricola, e tirar do solo os beneficios que elle pode proporcionar, tem necessidade de dirigir-se aos capitalistas á fim de que por meio do emprestimo dos seus capitaes lhes proporcionem os meios necessarios ao desenvolvimento d'aquella industria por isso se colocam na dependencia delles. Os Portuguezes por muitas circunstancias; por terem sido os dominadores da terra, por haverem ainda depois da independencia conservado a sua antiga posição com o predominio e quasi exclusiva applicação da industria commercial, são os que se acham possuidores desses capitaes; e por isso exercem uma decidida influencia sobre os proprietarios. Se pois procedermos á uma autopsia da Sociedade Brasileira, teremos o seguinte resultado:

1. a importancia, capitalistas - Portuguezes.

importancia secundaria - Proprie. de Terras.

terceira importancia, a industria, maxime a comercial - Portugueza.

Assalariados - Escravos.

E a massa da nação, o que é? Nada. O que the pertence? A miseria!!" (70).

A influência estrangeira no comércio era, incontestàvelmente, danosa. A Folhinha de Algibeira ou Diário Eclesiástico e Civil para as províncias de Pernambuco, Paraíba, Rio Grande do Norte,

(68). - A Voz do Brasil, n. ${ }^{\circ}$ 38, de 30-6-1848.

(69). - A Voz do Brasil, n.o 76, de 17-11-1848.

(70). - N. ${ }^{0}$ 30, de 12-10-1849. 
"Ceará e Alagôas para o ano de 1848, apresentava no Recife 23 comerciantes brasileiros para 54 estrangeiros, dos quais 20 inglêses, 3 norte-americanos, 9 franceses, 10 alemães, 1 holandês, 2 suiços, 1 dinamarquês e 8 portuguêses. O número de 1841, que se denomina Folhinha de Almanak, mostra-nos 22 brasileiros, 7 portuguêses, 18 inglêses, 4 norte-americanos, 7 franceses, 4 alemães, 2 holandeses, 1 suiço. Referindo-se aos médicos existentes no Recife, a mesma publicação informa-nos que, em 13 facultativos, 2 são inglêses (Leudon e Mayer), 2 franceses (Theberge e Breton) e 1 italiano (Ulisses Leonesi). Já no Diário Novo (71), lê-se um protesto

"acêrca da existência de Médicos, Cirurgiōes, Boticários e Parteiras estrangeiros, sôbre que tantas reclamações temos feito, e cujas providências anciosamente reclama o respeitável público"'.

O número de comerciantes portuguêses - basta ler $A$ Voz do Brasil, O Nazareno e o Diário Novo - entregues ao comércio a retalho, era incomparàvelmente muitíssimo maior que o apresentado na proporção acima, referente ao comércio grosso. Acresce, ainda mais, que os lusitanos se dedicavam ao sistema de empréstimo a juro, extorquindo os naturais 20 e até $25 \%$ por semana -

" 80 rs. por cada pataca por semana" como diz Figueiredo - o que representava um modo simples de passarem "ràpidamente do estado de vendelhões ao de capitalistas, amontoando dest'arte fortunas escandalosas, que com razão acendeu a indignação popular".

Em tempo, o Cousin fusco, com a sua aguda compreensão dos nossos problemas, alertara:

"E como a maior parte desses usurarios é composta de Portuguezes, essas exacções, ainda que autorizadas por lei, todavia concorrem poderosamente para a permanencia desse odio que o nosso povo vota a todos os naturais de Portugal, e são mui nocivas ao paiz, porque pela perspectiva de rapida fortuna concentram nas cidades e praças de commercio os emigrados portuguezes, que com mais vantagem para o paiz se poderiam occupar no interior da provincia, na agricultura ou criação de gado, em vez de exercerem esta profissão improdutiva e representam o papel de sanguisugas" (72).

Não tardaria, muito, sem nenhuma dúvida, os frutos de semelhante estado de coisas. Se era vexatória a situação na agricul-

(71). - N.0 108, de 13-12-1842.

(72): - Tomo II, págs. 18 e 19 . 
tura, o mesmo panorama se projetava quanto ao comércio, e até quanto à indústria nascente, motivando o célebre manifesto dos artistas de 1844, onde, entre outras coisas, se protestava contra a importação de técnicos estrangeiros, o que contribuiu para Nunes $\mathrm{Ma}$ chado, em plena campanha eleitoral, pronunciar um discurso sôbre a nacionalização do comércio, na oficina de um sapateiro, na Rua Estreita do Rosário, ou, como se chamava na época, rua do Rosário estreita (73). As conseqüências - e a campanha de $A$ Voz do Brasil prenunciava isso - manifestaram-se na agitação de dezembro de 1847, quando da reunião da sociedade Philo-Terpsichore e da festa do Arco da Conceição (74) e dos graves acontecimentos de 26 e 27 de junho de 1848 (75), sem falar nos distúrbios de 8 , 9, 10 de setembro de 1844 e 25 de setembro de 1845 (76) e na atitude de indisciplina da guarda-nacional, relatada pelo Diário de Pernambuco (77).

A rebelião Praieira, aparentemente, resultou da substituição do gabinete de 31-5-1848 (liberal) pelo de 29-9-1848 (conservador). A ascensão do partido conservador, afastado que estivera do govêrno, desde a subida dos liberais, em 2-2-1844, é apresentada como a causa única do movimento. Todavia, as suas verdadeiras raízes se encontram na insatisfação reinante na massa pela opressão exercida pela "feudalidade" territorial, aliada ao elemento estrangeiro. Um fator que também influiu, embora seja olvidado pela maioria dos historiadores, foi o exemplo da revolução de 1848, na França, revolução de aspecto mais social do que mesmo político. Diz-nos O Progresso:

“... O movimento europeu sempre ha produzido um grande bem no Brasil porque mostrou a facilidade com que eram derribados os governos que se isolam das respectivas nações, e que, menosprezando os clamores dos povos, só se lembram delles para extorquir-lhes impostos de mais e mais onerosos; e não duvidamos que dentro em pouco a opinião pública seja unanime em reclamar certas modificações na nossa constituição e leis organicas, afim de todos os poderes não serem absorvidos no executivo, $\mathrm{e}$ as provincias reduzidas a colonias do Rio. de Janeiro" (78).

E mais adiante:

“...Elles (os revolucionários franceses) fizeram reconhecer que a sociedade devia ao individuo uma indem-

\footnotetext{
(73). - Ver sôbre o assunto O Eleitor Pernambucano, n.o 2, de 19-8-1847.

(74). - Ver Diário de Pernambuco, n. ${ }^{\circ} 278$, de $9-12-1847$ e 280 , de 11-12-1847 ainda $O$ Lidador, $n .0235$, de 11-12-1847

(75). - Ver Diário de Pernambuco, o Lidador e o Diário Novo

(76). - Ver jomais acima citados.

(77). - N.o 288, de 21-12-1847.

(78). - Tomo III, pág. 43 .
} 
nisação de sua herança confiscada; e, como primeiro pas-. so nesta estrada fecunda, o estado reconheceu o direito que todo o homem tem de viver do seu trabalho" (79).

Por sua vez, A Reforma (80), espetacularmente declarava em: entusiástico Aviso:

"A Reforma adhere á declaração do direito ao trabalho proclamado pela jovem Republica franceza, e roga a todos os seus colegas da imprensa o favor de adoptarem ou cambatterem esta declaração que lhe parece propria: para servir de bandeira ao partido progressista e facilitar a classificação das diversas opiniões".

Esta declaração está concebida nos têrmos seguintes:

"O Governo deve a todo o cidadão a Instrução gra-. tuita; meios de subsistencia e socorros no caso de velhice ou molestia".

Não poderia deixar de ecoar no meio do povo, preparado pela pregação dos jornais e de alguns líderes, a repercussão de certas me-. didas do govêrno proviśório francês, partidas, especialmente de. Louis Blanc. Medidas como o direito ao trabalho - que, aliás, depois foi incluído no Manifesto ao Mundo, em janeiro de 1849, como reinvidicação do movimento da Praia - e as fábricas nacionais repercutiram, certamente, em um povo tão explorado por uma oligarquia de latifundiários e uma burguesia adventícia.

A Praia foi um dos raros movimentos de massa em nossa História política. Geralmente, as nossas revoltas têm sido mais resultantes de impulsos das elites intelectuais do que mesmo impelidas pelo povo. A contribuição popular apresenta-se reduzida ou então tem, antes, provindo da pregação de bacharéis e frades reunidos em Areópagos (81). Na Praieira, vemos a fôrça dos movimentos po-

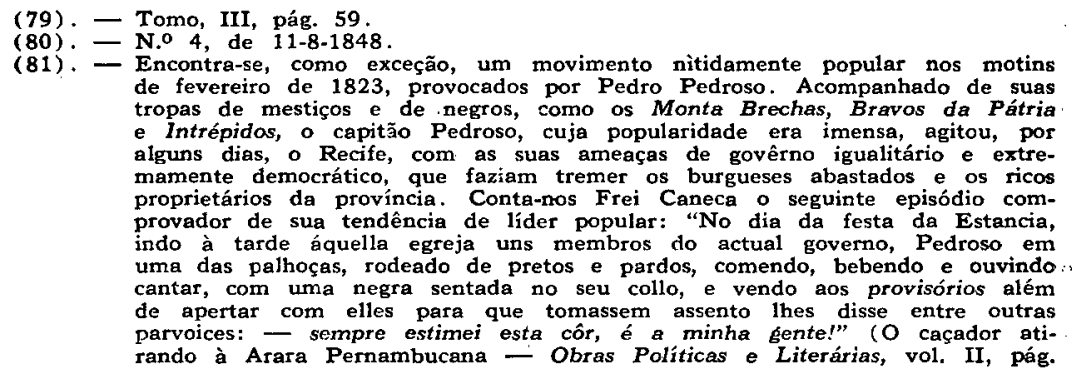


pulares, levando os líderes, na maioria políticos sem grandes pretensões a reformadores sociais, a adotarem um programa, às vêzes, por êles combatido em momentos anteriores e até na 'mesma ocasião (82). :

E a grande fôrça da Praieira reside, justamente, no seu caráter de explosão de aspirações populares. Os historiadores, em sua quase totalidade, têm mal compreendido o espírito da Praia, confundindo-o com o partido liberal ou luzia, do mesmo modo que não têm percebido o aspecto original do partido guabirú, que não pode ser confundido com o saquarema ou conservador (83). Os dois partidos que se degladiaram em Pernambuco, no período de 1842 a 1850, e mesmo mais àlém, não representavam, apenas, o velho antagonismo de liberais e conservadores, identificados pelas mesmas aspirações de conquistas das posições de govêrno, os quais partidos mereceram do visconde de Albuquerque, parodiando Disraeli,

159). E é bem significativa a quadrinha cantada, naquela época, pelós seus soldados:

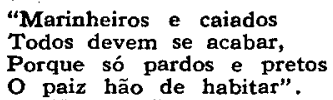

(82). - Basta citar o Manifesto ao Mundo, de 1-1-1849, elaborado por Borges da Fonseca e assinado por todos os chefes militares, onde se encontrava a bandeira de revolta, condensada na convocaçäo de uma Assembléia Constituinte, que deveria tornar realidade as seguintes reivindicaçōes: "1.0 o voto livre e universal do Povo Brasileiro. 2.0 A plena e absoluta liberdade de comunicar os pensamentos por meio da imprensa. 3.० $\mathrm{O}$ trabalho como garantia de vida para o Cidadão Brasileiro. 4.0 O commercio a retalho só para os Cidadãos Brasileiros. 5.0 A inteira e effetiva independencia dos poderes. constituidos. 6.0 A extinção do poder moderador, e do direito de agraciar. $7 .^{\circ}$ O elemento federal na nova organização. 8.0 Completa reforma do poder judicial, em ordem a segurar as garantias dos direitos individuais dos Cidadãos. 9.0 Extinção da lei do juro convencional. 10.0 Extinção do actual systema de recrutamento". ( Apud Figueira de Mello - Chronica da Rebellião Praieira, págs. 194 e 195). A divulgação dêsse documento causou espanto nos próprios praieiros mais conservadores do Recife, pois, muitas idéias colidiam com o princípio monárquico e iam bem mais além das pretensões dos chefes políticos do movimento, tanto que o Diário Novo chegou a considerá-lo apócrifo e arma de descrédito lançada pelos guabirús. Todavia, o pensamento vigorante no Manifesto, não foi uma simples manifestação do espírito irrequieto de Borges da Fonseca, pois não sòmente consagrava velhas aspiraçóes populares (ver, entre outras provas, a petição levada à Assembléia Provincial, pelos "srs. Serpa Brandão, juiz municipal de Iguarassú, Francisco Borges Mendes, a creoulo Crilio e outros", e datada de 27-6-1848, in $O$ Lidador, n. ${ }^{\circ} 293$ de 30-6-1848), como também contava com o apôio dos chefes militares da revolta, como vemos pela seguinte declaração de Borges da Fonseca, em carta datada de 12-1-1849, de Sibiró de Serra, MS existente no Inst. Arqueológico, Histórico e Geográfico Pernambucano: "Posso assegurar ao publ.o que os inclitos Moraes, Roma, João Paulo, Lucena, Leandro e eu nunca nos separamos, e nem em toda esta campanha havemos tido a menor divergencia: pensamos igual, e operamos do mesmo modo".

(83). - Assim como não é possível identificar-se, por completo, o partido praieiro com o luzia, também não é concebivel confundir-se o guabirú com o saquarema ou o saquihavemos ou saquiemos, como é costume de $A$ Voz do Brasil 
a alúsão ferina de que "não há nada mais parecido com um luzia: do que um saquarema". A estrutura da Praia diferencia-a das organizações políticas do seu tempo. Afirma o Maccabeo (84):

“...Esse partido da praia, partido generoso, parti-. do formado pela reação necessaria contra a imoralidade,

denominá-1o (n,o 75 de 13-11-1848). O têrmo guabirú foi usado para designar o velho partido oligárquico do barão da Boa-Vista, que vinha desenvolvendo-se desde 1837, data da ascenção da família Rego Barros-Cavalcanti ao poder. A princípio, conhecido pelo nome de baronista e de trapicheiro, foi, desde fins de 1844 , batizado pelo de guabirú. O Guarda Nacional, n. 129 de 25-11-1844, em artigo intitulado Nova denominação dos baronistas, diz: "O mato que outróra seguia as pisadas da Praça, e imitava tudo quanto nós aqui faziamos, já não está assim, e á alguns respeitos dá-. nos hoje excellentes liçoens. Desde que appareceo em campo o Honorio, e o Barão da B. Vista, ambos bem conhecidos por seos feitos, temos aqui chamado ao partido, ou lado d'esses heroes de theatro, reorganizador, baronista, trapixeiro, etc., etc.; mas nenhum desses apelidos significava verdadeiramerite e com clateza o que era esse partido: entretanto o Bonito acaba de dar-nos huma bella denominação a essa gente que sustenta os principios de 19 de Setembro, e vem a ser a de - Euabirús!!

São pois os baronistas verdadeiros guabirús, porque seguem em tudo e por tudo a condição desses ratinhos. O guabirú furta, e corre, teme qualquer individuo, e ao ver o gato é capaz de precipitar-se nos maiores abysmos, o baronista, que é, digão lá o que quizerem, hum verdadeiro guabirú, furta e corre, e nega e tem mais medo de um praieiro disposto do que de tudo quanto ha. Fique pois adoptada a denominação do Bonito, e isto posto sejam proclamados os baronistas com applausos, e contentamento - os guabirús de Pernambuco. Para provar que tudo quanto digo é verdade farei algumas reflexões, e por ellas vejão os leitores se o partido do Barāó é ou não é guabirú. No Bonito o ex-Delegado José Joaquim Biserra de Mello, que já foi republicano, regressista, chimango, caranguejo, caramurú, praieiro e agora é baronista, ou por outra agora é Francisco Domingues e Medeiros, teve seos medos de huns gatos que andavão de noite miando nas ruas da Villa; e só por isso reunio forças e estabelleceo hum destacamento com soldo de tropa de linha em campanha".

Parece que a denominação calou logo na opinião pública, tanto assim que o Diário Novo, n. ${ }^{\circ} 276$, de 17-12-1844, tratando da questão das cédulas falsas, já chama os baronistas de guabirús. Por sua vez o n.o 8, de 11-1-1845, do mesmo jornal, diz que "O Diário Velho de 9 do corrente vem com um chiado de guabirú".

o partido baronista - o futuro guabirú - tem um caráter próprio, um aspecto original, representando não tanto as pretensões políticas dos saquaremas, mas sim as aspirações locais da classe opressora - uma oligarquia de senhores de Engenho - dominando social e econômicamente a província. Comenta o Diário Novo (n. ${ }^{\circ} 30$ de 11-7-1849) "Na facção que hoje se ostenta orgulhosa e soberba existem tres grupos diversos e muito distinctos - o da família Cavalcanti-Rego Barros, vulgarmente chamado guabirú; o da praia-nova; e finalmente o dos saquaremas propriamente ditos. Este grupo $\left(o 1^{\circ}\right)$ não tem principios, não tem pensamentos: quer 0 poder, seja como for; seu fito é avassalar o paiz á seus caprichos e desvarios, seu fím é dominar tudo e tomar-se um grupo de Suzeranos, e para consegui-io serve a todos os partidos, vive em continua contradição e inconsequencia, e . ora é luzia, ora é retrogrado, ora é republicano, conforme o rumo em que corre o venta.

A praia-nova tem um só principio, um só pensamento, esse principio e pensamento é - a elleição de trez ou quatro de seus membros.

Resta $03 .^{\circ}$ e último grupo, o dos Saquaremas propriamente ditos. Ora, em abono da verdade, ha em Pernambuco corcundas bem intencionados, isto é; homens que entendem que os saquaremas são uns anjos do céo, que são monarchistas sinceros, amantes de Deos e do Imperador; e esses homens com quanto queirão o governo absoluto, com tudo não apoião nem os Cavalcantes, nem praia-novas". Há nesse comentário uma preocupação bem evidente de isolar os guabirús dos saquaremas, dando aos primeiros características que os diferenciam dos conservadores pròpriamente ditos. $\mathbf{E}$, de fato, as pretensões dos baronistas tinham um sentido mais local, mais de acôrdo com os seus interêsses imediatos de grandes senhores de terras. Tanto que náo trepidavam em se unir a republicanos declarados, como Borges da Fonseca.

(84). - N.0 12, de 14-8-1849. 


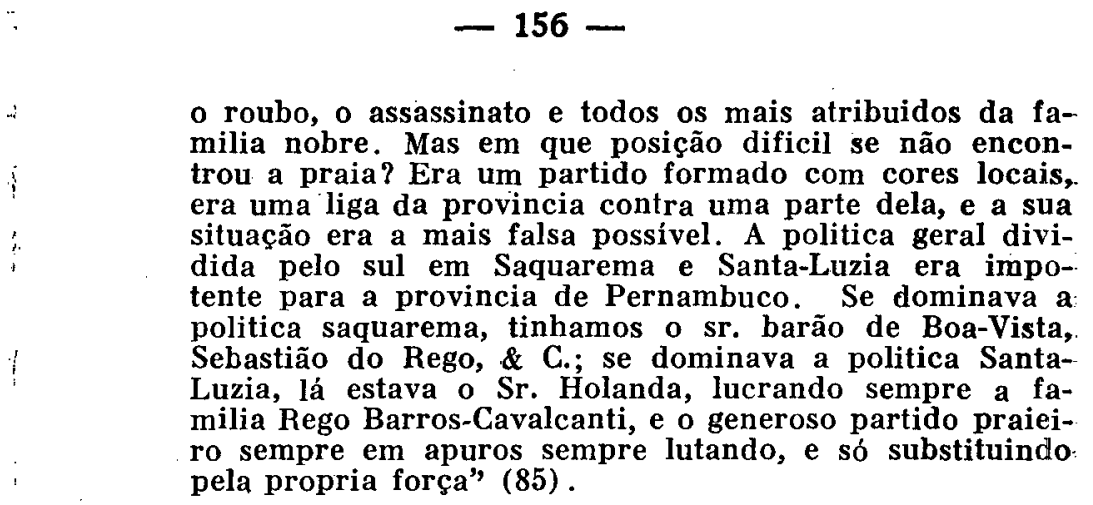

Por sua vez percebeu o sentido do partido guabirú

"que não tendo bandeira política, se compõe dos. fidalgos Rego Barros-Cavalcanti, dos ambiciosos e aventureiros ciganos" (86).

Tendo o partido praieiro nascido com o Diário Novo, foi adquirindo, com o tempo, um sentido tão altamente revolucionário, especialmente na sua ala extremo-esquerda, aliás, a que fêz a revolta, que muitos dos seus líderes se alarmaram com o desenrolar dos. acontecimentos.

Nabuco foi dos raros a ver longe:

"Na verdade como foi reconhecida pelos Cavalcantis mesmo, é que a Praia representa a população de Pernambuco em sua vasta maioria; era a encarnação da alma, do sentimento da aspiração popular... Nós não podemos julgar hoje essas epochas de que não sentimos as paixões; é provavel porem, que o movimento de 1848 tenha preenchido uma funç̧ão util e fosse uma valvula: necessaria" (87).

Afirma-nos o velho Felix Cavalcanti que o nome de Praieiro foi dado por Sebastião do Rego Barros - o célebre Bestalhão da Guerra dos pasquins da época de Chichorro da Gama - "por escarneo", pelo fato da tipografia do Diário Novo ser na rua da Praia (88). O n.o 35 do Diário Novo de 13-2-1844 diz:

"Os jornaes da policia, todas as vezes que nos querem combater, nos denominam opposição praieira, e tambem á algumas pessoas temos ouvido em particular essa

\footnotetext{
(85). - "Os Praieiros têm uma historia politica singular. Elles nāo eram liberaes priamente não foỉ senão um movimento de expansāo popular". (Nabuco, Um Estadista do Império, tomo I, pág. 75).

(86). - U. E Estadista do Imper de 28-8-1849.

(87): - De um discurso publicado em $A$ Província de 2-2-1898.

(88). - Memórias de um Cavalcanti, pág. 60.
} 
denominação. Se nos chamão opposição da praia, só para nos darem um cognome derivado da situação em que se acha, a typographia opposicionista, nós não o regeitamos, uma vez que serve elle de fazer-nos conhecidos".

Já na segunda metade de 1844 , o próprio Diário Novo aceita - o epíteto e deixa de chamar, como fazia antes, à sua organização política de partido nacional para chamá-la de praieiro. $\mathrm{O}$ n. ${ }^{\circ} 179$ de 20-8-1844 traz um artigo intitulado Triumpho da Praia. $\mathrm{O}$ n. ${ }^{0}$ 182 de 23-8-1844 fala no "vitorioso exercito da praia". E assim por diante. Os demais números vão consagrando a denominação. Com o passar do tempo, o partido praieiro foi congregando as aspirações populares, foi tornando-se um partido de massa, um partido dos cavalgados, onde se conjugavam ardentes manifestações subterrâneas de reivindicações, ao lado de preocupações meramente políticas de muitos dos seus corifeus. Alguns dêles, fazendo-se de líderes populares, vestindo roupagem de tribunos da massa, com o intuito de arrastar o povo para o seu seio, êsse povo já cansado do domínio opressivo dos Cavalcantis, que já por tanto tempo "cavalgavam política e socialmente a Província" como disse, espirituosamente, o prof. Gilberto Freyre (89).

Sente-se, claramente, a preocupação com que os jornais baronistas distinguem a Praia do partido liberal. No n. ${ }^{\circ} 9$ do Saquarema de 31-8-1846, lê-se:

“...Os Santa Luzias, já não estão muito de accordo com os praieiros, aos quaes acusão de muito exigentes, vingando-se os segundos em acusá-los de egoistas. Achamos razão nos primeiros, que em verdade defendem principios, que postos que sejão contrarios ás nossas ideias, e os julguemos inteiramente subversivos para a Sociedade Brasileira, nem por isso deixão de ser principios e nós respeitaremos sempre as convicções de todos os homens honestos; mas os praieiros, que não tem ideias, nem principios e nem honestidade, que não passão de miseraveis ganhadores, cuja precaria existencia politica depende absolutamente da vontade do governo, o qual para reduzi-los á nulidade de que nunca devião ter saido, basta mandar para Pernambuco hum presidente menos faccioso do que o sr. Chichorro, ou falando precisamente, hum homem que tenha brio e pudor, e que não jogue despejadamente a sua reputação, he cousa que faz rir vê-los acusar os Santa Luzias, porque não sacrificão a bem delles, o paiz e a paz do imperio".

Há, além disso, na Praia, uma ala avançada - a esquerda do partido - que defendeu os mais arrojados princípios de reivindicação popular e que levou o partido praieiro à revolta: - o cha-

(89). - Prefácio às Memórias de um Cavalcanti, pág. 16. 
mado grupo dos Cinco Mil: Um dos seus jornais, $A$ Voz do Brasil chegou a ser estigmatizado pelos praieiros de projeção, como vemos nas orações pronunciadas pelos deputados da Praia na Câmara Geral, quando das discussões a respeito dos incidentes de 26 e 27 de junho de 1848. A origem dos Cinco Mil ainda não fói bem esclarecida. Diz Alfredo de Carvalho (90):

"Enumerando as manifestações de regosijo com que foi recebido em Pernambuco o advento do ministerio de 2 de Fevereiro de 1844, noticiou o Diario Novo uma passeiata de cinco mil pessoas, numero exagerado que fez os conservadores dizerem que os praieiros eram - cinco mil".

Aliás, o referido jornal (91) fala em "mais de cinco mil pessoas". Pereira da Costa dá, entretanto, outra interpretação:

"Os cinco-mil representavam o partido que promovia a nacionalização do comercio á retalho; e promovendo o panfletário e agitador Antonio Borges da Fonseca una representação ao governo sobre o assumpto, e mandando-a assignar por diferentes pontos da provincia, dizia que o numero de subscritores atingia a cinco mil, vindo dahi a denominação dos partidarios da ideia e extensiva depois aos liberaes ou praieiros" (92).

Parece que havia a tendência, na época, de situar tudo dentro dêsse número, tanto assim que Maximiano Lopes Machado figura saliente da revolta na província da Paraíba - diz no seu Esbôço Biográfico do Conselheiro Senador do Império Antônio Pinto Chichorro da Gama (93), que o cadáver do tenente Luiz da Costa Bezerra Bimbert foi acompanhado pelas ruas do Recife "por mais de cinco mil pessoas" (94). Possuíam êles um Hino dos Cinco Mil (95), havendo, ainda, um Hino Nacional dos Cinco Mil (96). Nesse jornal, no seu n. ${ }^{\circ}$ 6, de 2-10-1847, além do Pelo Signal dos Cinco Mil - que também saiu em $A$ Tempestade, n. ${ }^{\circ} 1$ - há o Padre Nosso dos Cinco Mil. Formando um grupo ativo e exaltado, apresentavam uma certa organização com tendência profundamente de esquerda. Pereira da Costa acentuou que, em 1846,

"O Postilhão faz referencia aos cinco mil, como um centro político mais ou menos organizado" (97).

Enfàticamente, êles clamavam no seu Hino:

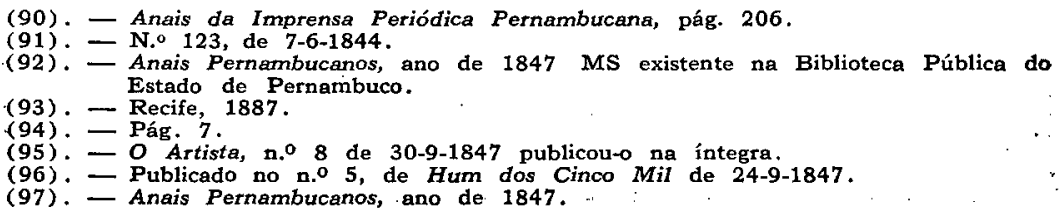


"Se o despotismo atrever-se

A sahir do seu covil

Ferro e fogo encontrará

Nos valentes cinco mil" $(98)$.

$\mathrm{E}$ até senadores pretendiam ter elementos para fazê-lo, como se vê do soneto de A. L. P. de Carvalho em $A$ Tempestade (99):
"Chichorro! Oh! memoria do Brasil!
Senador has de ser em violencia
Com os votos liberaes dos cinco mil".

Quem sabe das relações dos Cinco Mil com a sociedade $V$ igilante, que, como parece, tinha tido, por sua vez, ligação com a Sociedade Jardineira ou Carpinteiros de S. José, fundada em 1828? Pereira da Costa (100) mostra-nos que a Sociedade Vigilante era de "um caráter inteiramente político" embora "sob a forma e fins maçônicos" e que tinha

"associados espalhados por todos os municipios da provincia, valentes propagandistas da bandeira que arvorara, cujos principios e ideais, ignoramos, sabendo apenas, que eram as mais liberaes possiveis".

Deu origem, posteriormente, quando de sua extinção, pois "foi muito perseguida", à Associação Imperial Pernambucana que se tornou o órgão do partido praieiro. Quem sabe se $A$ Vigilante não manteve contacto com os Cinco Mil, irmanados nas mesmas tendências e preocupações? A figura de Borges da Fonseca, na direção da Vigilante, é um fato que não se pode desprezar. E' inconteste que os Cinco $M$ il representavam a facção extremada da Praia e defendiam idéias avançadas de reivindicações sociais, algumas delas propendendo para manifestações desordenadas e até anárquicas. Mais do que em Hum dos Cinco Mil, jornal dirigido pelo padre Capistrano de Mendonça e que parecia ser o órgão do grupo, encontramos em $A$ Voz do Brasil, de Ignacio Bento de Loyolla, o maior veículo de propagação de suas aspirações. E não se venha dizer que a Praia tenha negado qualquer solidariedade e ligação com a atividade dêsse jornal. Oficialmente pode ser, mas de fato se sente a afinidade entre o pensamento de Ignacio Bento de Loyol-

\footnotetext{
(98). - O Artista, n. ${ }^{\circ} 8$.

(99). - N.O 3, de 12-9-1847.

(100). - Anais Pernambucanos, ano de 1843.
} 
la e os jacobinos do partido praieiro (101). Nos vários discursos que sobressaltam a população do Recife, vemos constantes alusões . à interferência dos esquerdistas da Praia. Referindo-se ao incidente de setembro de 1845, afirma o Lidador (102):

"Os ardentes, os cinco mil, attrahidos pelo signal correm amotinados".

Ao mesmo tempo, o órgão guabirú acentua a origem popular do grupo e as suas tendências avançadas e reformistas:

“...Esses esfarrapados Cinco Mil, que hoje atacão a nossa segurança e ameação a nossa propriedade” (103).

A Praieira foi a resultante lógica da pressão dêsses elementos de massa (104). O grupo de orientação puramente política foi arrastado a acompanhá-los, impelido pela fôrça das circunstâncias e pelo impulso dos acontecimentos (105). Para aquêles políticos preocupados, ùnicamente, com as mudanças de gabinete e com as oscilações dos partidos, não interessava, no momento, uma luta ar-mada. Talvez fôsse fácil a derrubada dos conservadores, tão instáveis na ocasião, tão inseguros ainda, pelos meios puramente pacíficos, sem a necessidade do recurso às armas, tão precário e incerto e que poderia, como de fato aconteceu, redundar num longo e penoso ostracismo, sumamente desagradável, para quem via tudo em função da atividade partidária, relacionada com a politicagem de

\footnotetext{
(101). - E' impossível desprezar-se a importância dêsse jornalista nos acontecimentos que prepararam a Praieira e nos posteriores a ela. Diz o Lidador (n. ${ }^{\circ}$ 294 de 4-7-1848): "...Quem he o Sr. Loyola? Praieiro, como tal sempre havido e declarado; oficial da secretaria da assembleia praieira, preso e processado pela parte que tomou nos acontecimentos de 26 e 27 ". E era tão intensa a sua atuação revolucionária que, ao iniciar-se o movimento armado, foi logo detido, quando outros continuaram livres. Eis o que diz o chefé de polícia Firmino Antônio de Souza em ofício ao Presidente da Província: "Achando-se preso desde hontem p. ordem minha pelo Delegado do 1," Dist.o Ignacio Bento de Loyola Redactor da Voz do Brasil, como indiciado nos crimes classificados nos Arts. 68 e 85 do Codigo Penal manifestados em alguns numeros do mesmo Periodico, e convindo, q. seja posto á bordo d'alguma embarcação de Guerra, rogo á V. Exa. as suas ordens para que se effectue este meo proposito á bem do serviço publico. Deus guarde á V. Exa. Secretaria de Policia de Pernambuco 4 de Janeiro de 1849". (MS existente no Arquivo do Estado de Pernambuco).

"(102). - N. 55 de 1-10-1845

(103). - $O$ Lidador, n. ${ }^{\circ} 236$ de 14-12-1847.

(104). - Nabuco percebera, em verdade, a tendência da revolta: "Não se pode deixar de reconhecer no movimento praieiro a força de um turbilhäo popular. Violento, indifferente a leis e a principios, incapaz de permittir em seu seio o minimo desacordo, empregando sempre meios muito mais energicos do que as resistencias exigiam, embriagardo-se, dos seus excessos de autoridade, tudo isso é exacto do dominio da Praia, e esses são os caracteristicos proprios da democracia. Mas a verdade é que a Praia era a maioria, era quasi o povo pernambucano todo... Muito provavelmente a Praia representava a queixa de uma população adiantada de instinctos contra a sua triste condição". (Um Estadista do Império, tomo I, págs. 74 e 75). E afirma, também: "... A Praia dispunha da massa popular e tinha sempre promptos, esperando um seu aceno os elementos precisos para uma revolução". (Ob. cit., tomo I, pág. 68).

(105). - "A politica complicava-se com um fermento socialista", como disse Joaquim Nabuco. (Ob. cit., tomo I, pág. 67).
} 


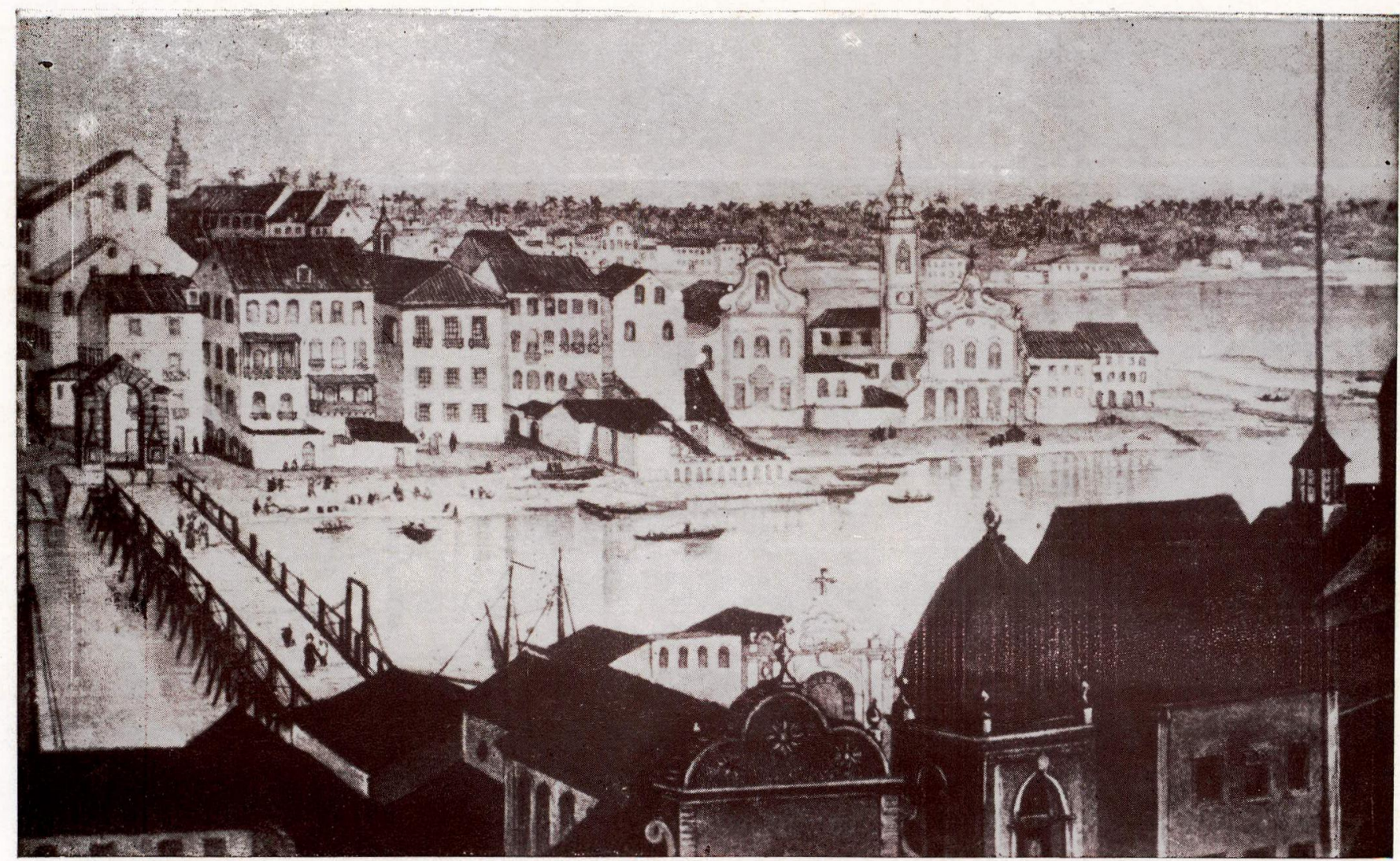

Recife na primeira metade do século XIX. Vê-se um trecho do bairro de Santo Antônio com a ponte, hoje, Maurício de Nassau e um dos arcos, justamente o de Santo Antônio. 


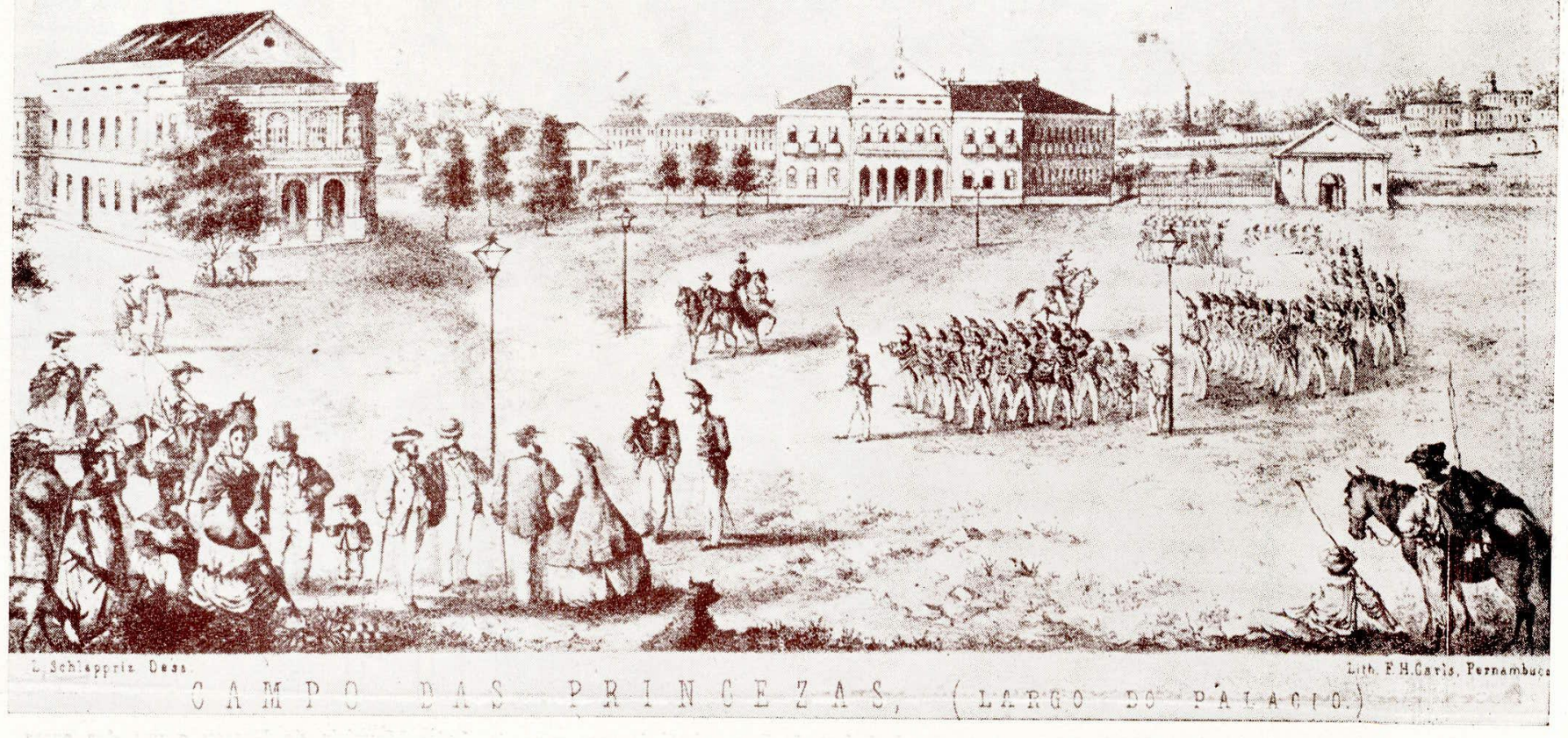




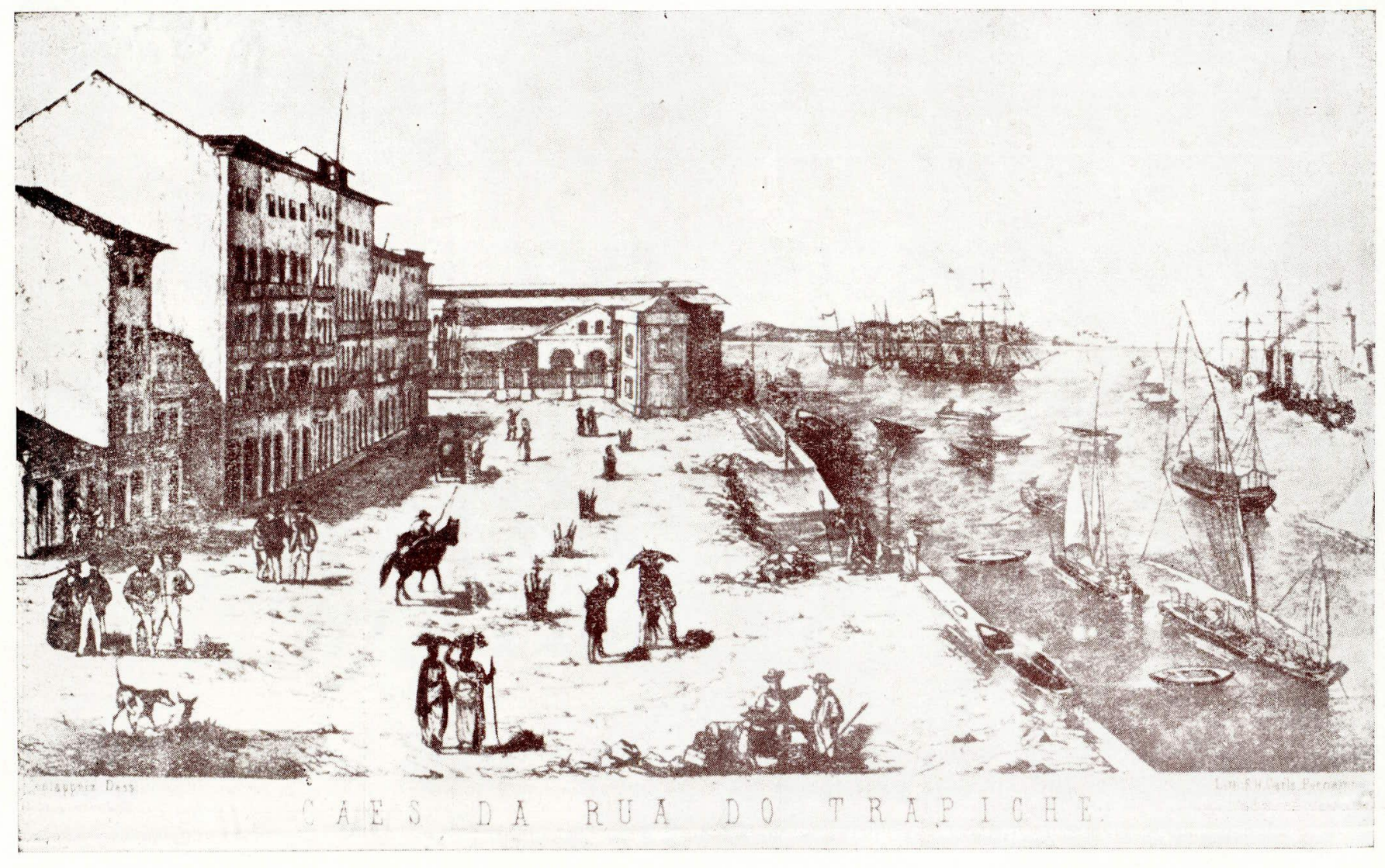




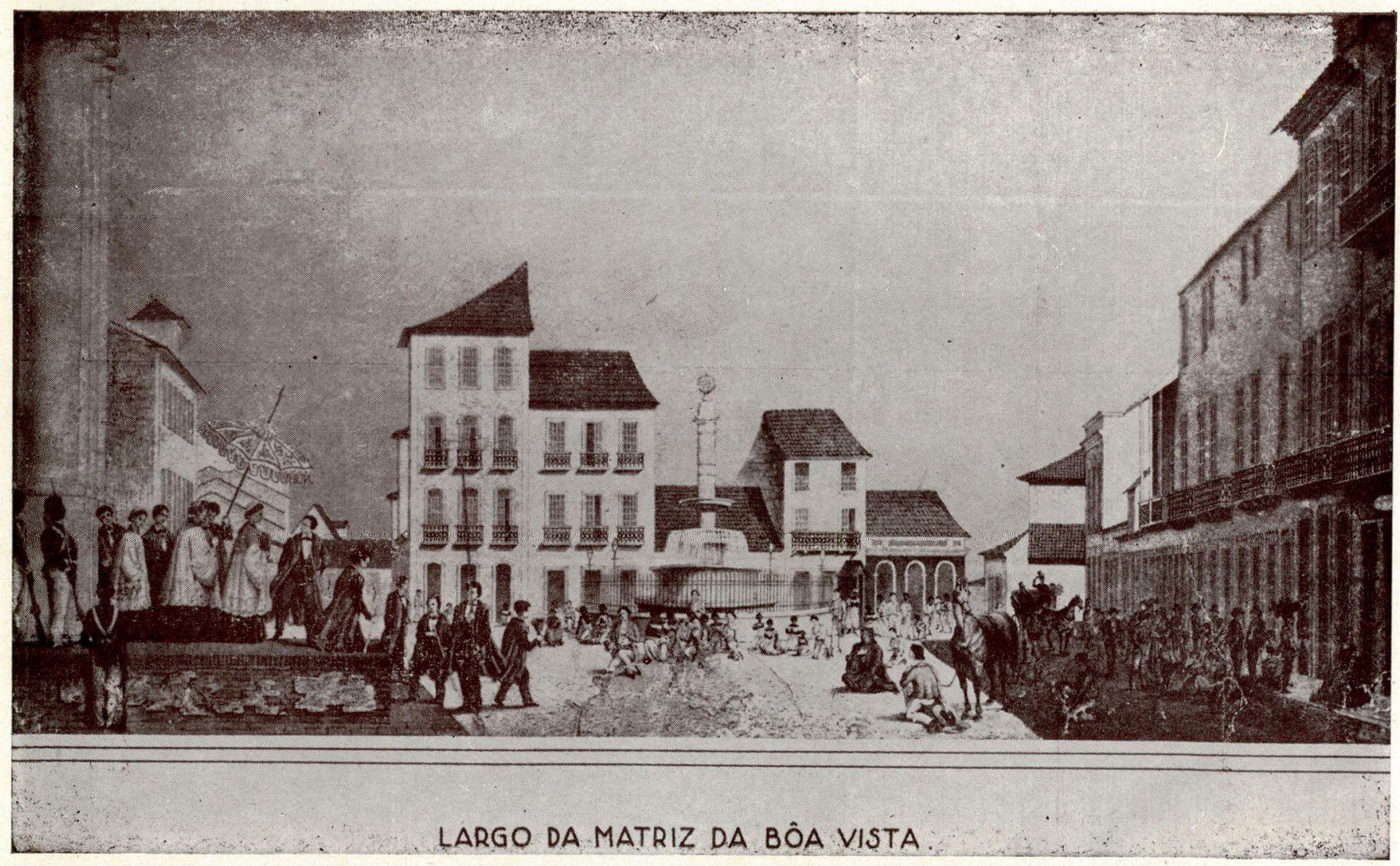




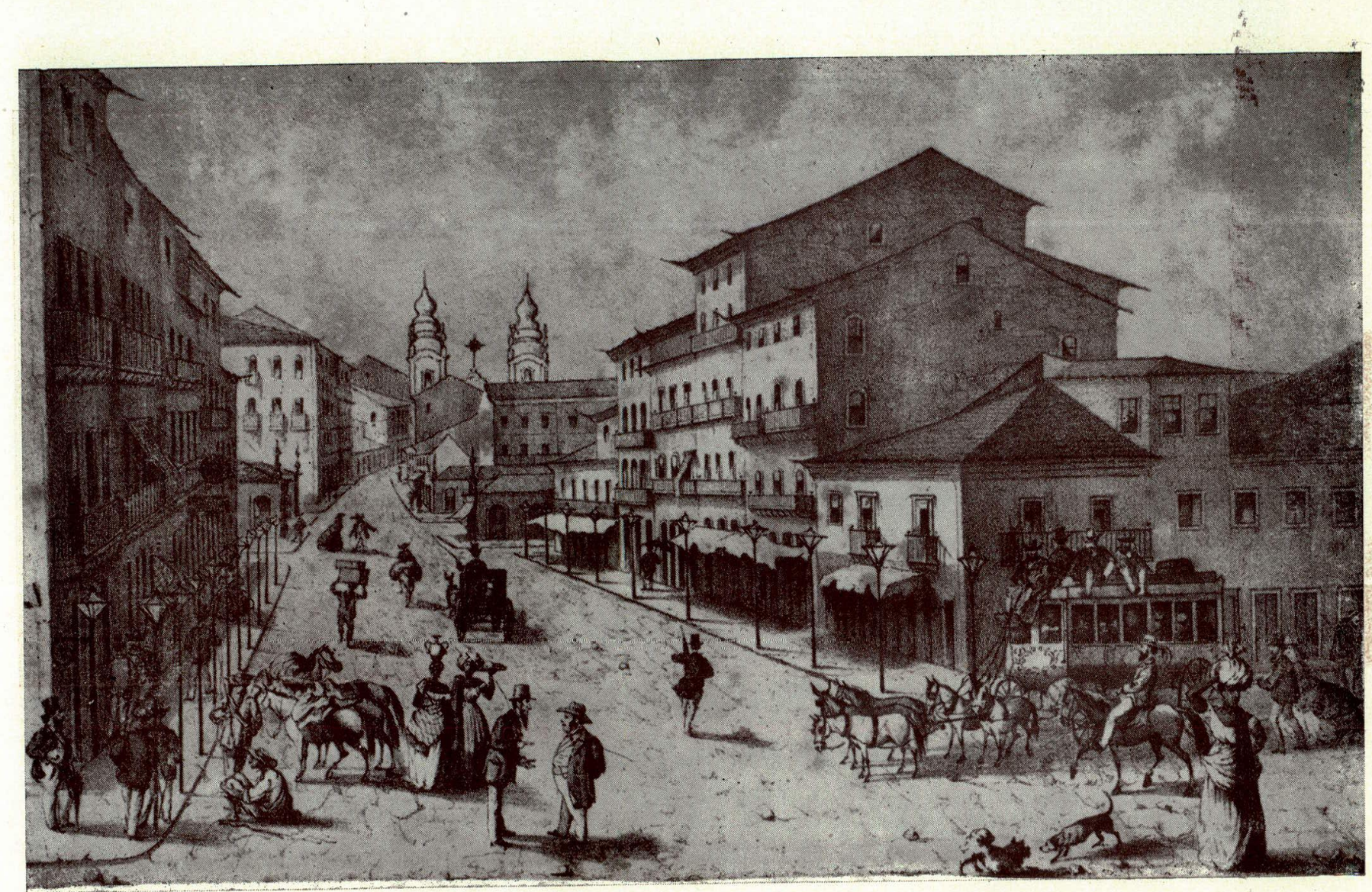

Este trecho da rua do Crespo é contemporâneo da Revolta Praieira. 


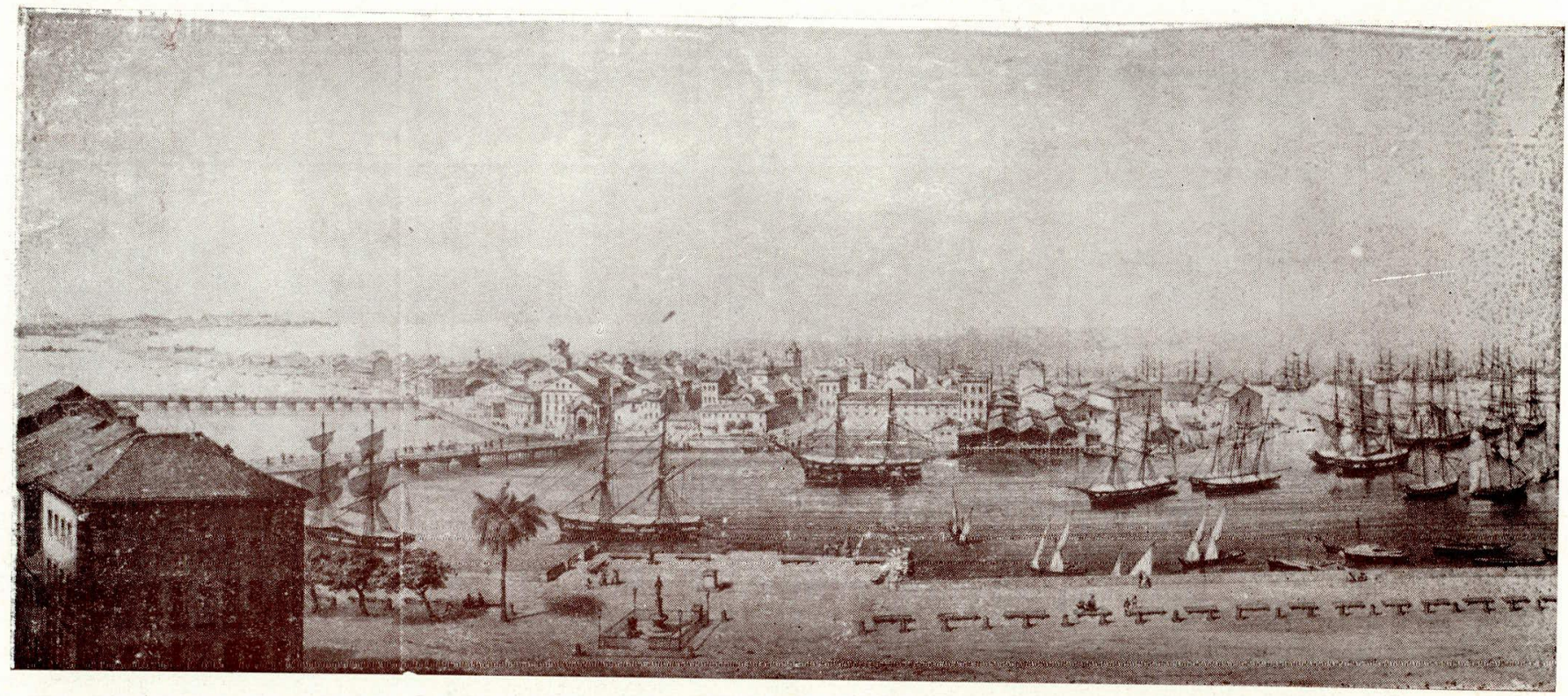

Trecho do Resife (meados do século XIX). 


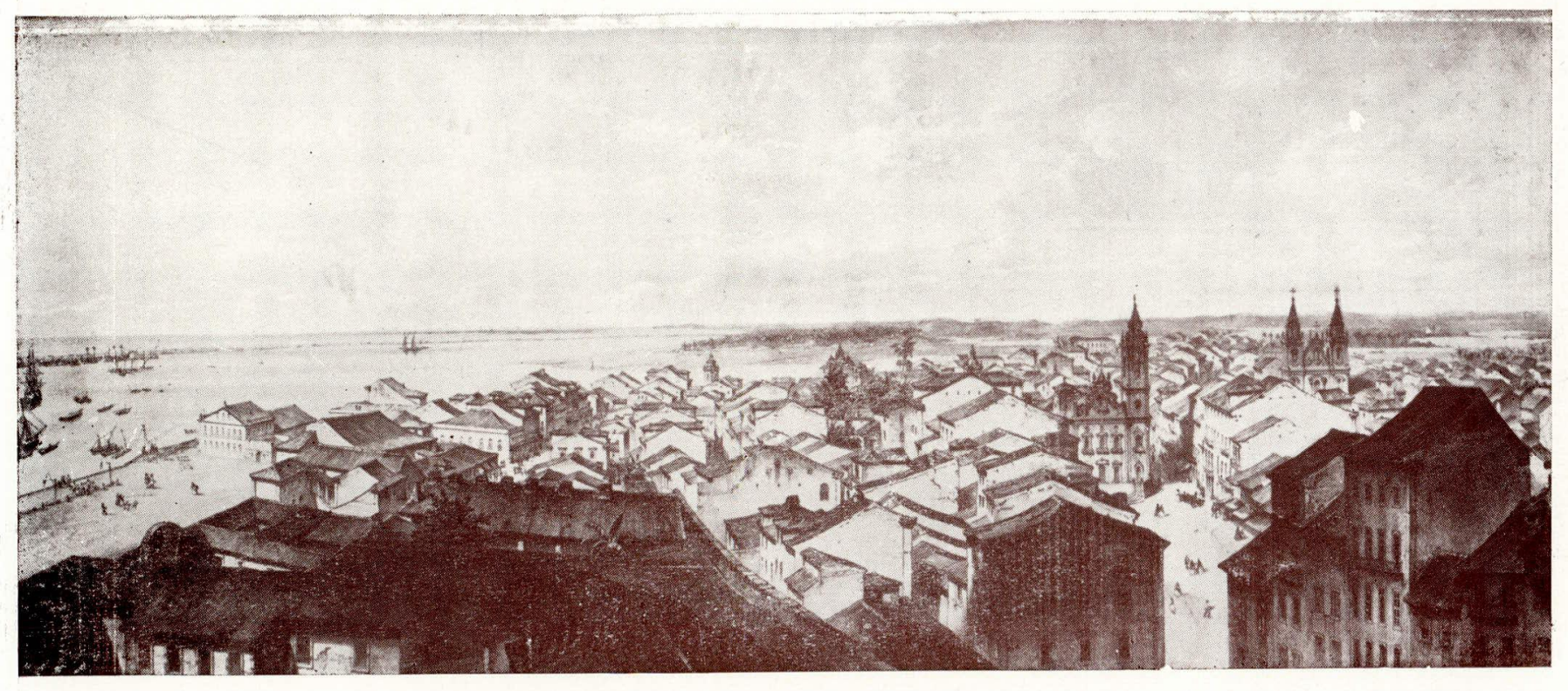

Trecho do Recife (meados do século XIX). 


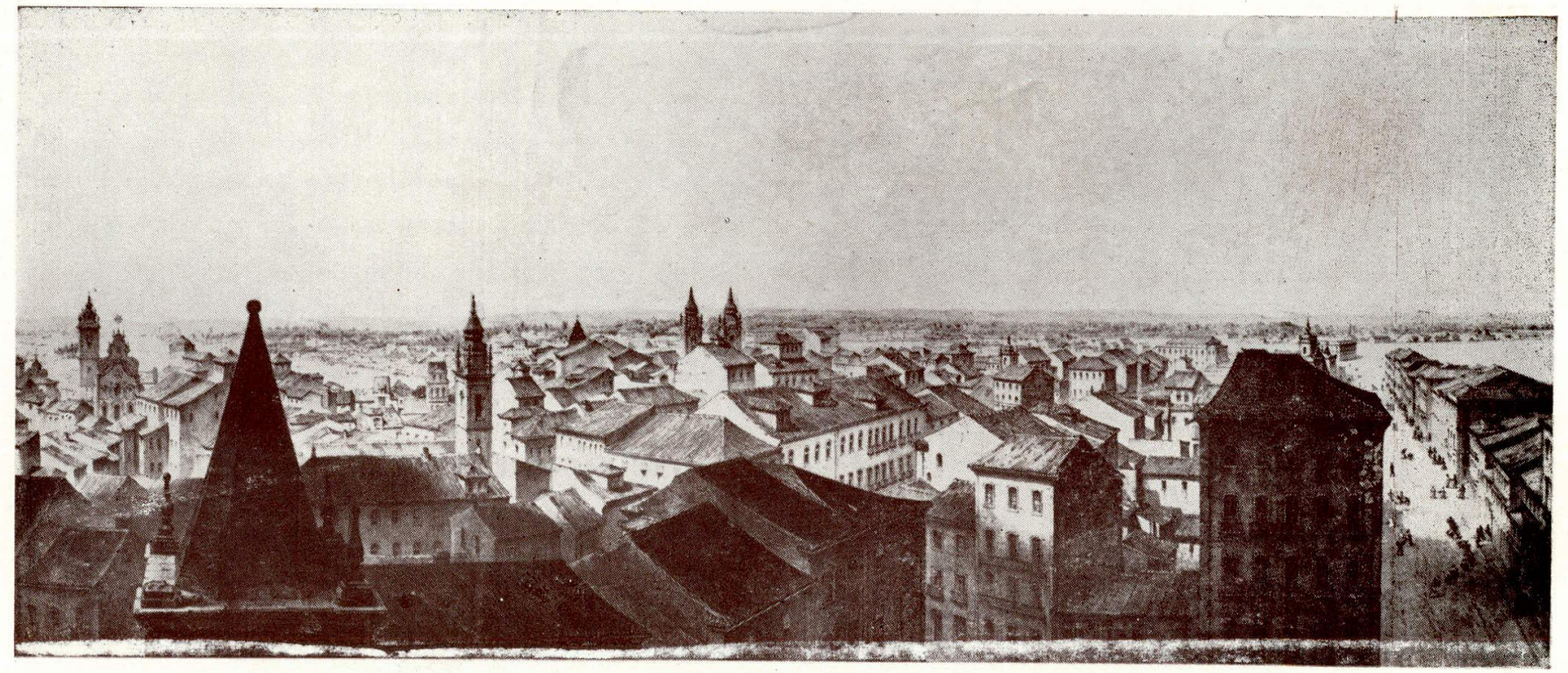

Trecho do Recife (meados do século XIX). 


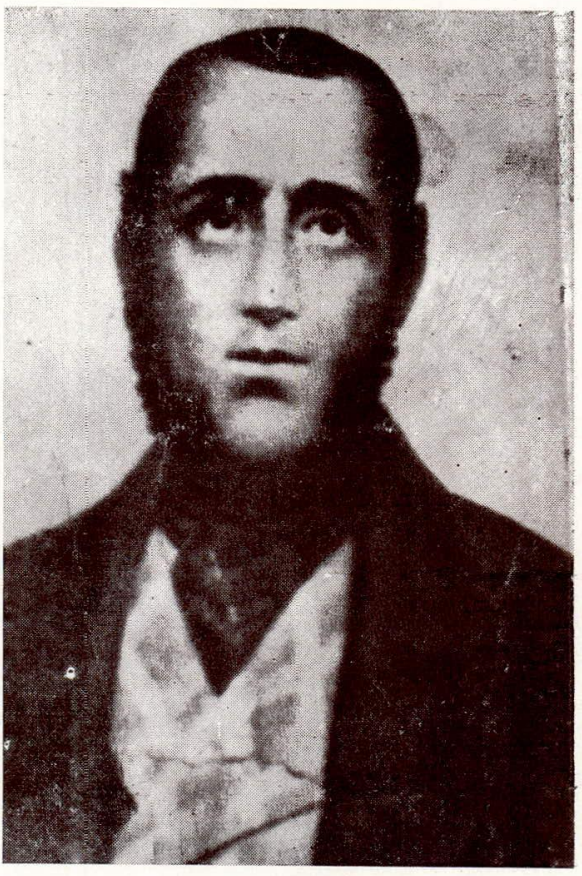

Nunes Machado 
càmpanário. A revolução não foi almejada pelos grandes líderes praieiros. Numa reunião realizada na Côrte, estabeleceram os depu-. tados da Praia a necessidade de evitar-se, a todo o custo, o choque armado. E Nunes Machado, com os seus correligionários já de armas na mão, já se tendo ferido os primeiros entreveros, ainda mantinha a esperança de apasiguar os ânimos cuja exaltação êle, afastado no Rio, não podia avaliar. Incapaz de resistir aos amigos e o marquês de Paraná acentuava que o grande liberal era homem de tôdas as coragens, exceto dessa - foi tragado pelo torvelinho que, se em parte atiçara, tudo fizera, quando vira a gravidade da situação, para desfazer. Joaquim Nabuco diz:

"A revolta era inevitável, não porque os chefes políticos da Praia a promovesse, mas porque eram impotentes para dominar os seus correligionários" (106).

A participação popular no movimento é grande. Qualquer autor que abrirmos, ou qualquer jornal que folhearmos, fornecem dados comprobatórios desta tese. A administração de Chichorro da Gama tinha contribuído, grandemente, para o fortalecimento do partido praieiro e para o incentivo às pretensões da massa. A atitude enérgica do presidente da Província, pondo-se, declaradamente, ao lado dos cavalgados, desmoralizando a "feudalidade" territorial, representada nos Cavalcantis e castigando, com a sua polícia, os desmandos e os crimes dos partidários do barão, trouxera-lhe 0 apôio completo dos elementos populares, dos "membros dos clubes dos mulambos", na expressão irônica do Lidador. A divulgação dos crimes de um José do Rego, de um Chico Macho, de um José Maria, o conhecimento dos atentados praticados no Arraial, a apreensão de escravos roubados (107), tudo isso fortalecia, no seio do povo, o prestígio de Chichorro da Gama e aumentava a popularidade do partido praieiro. A vigilância da polícia, intervindo nos engenhos, ousando entrar nos "góticos castelos" dos potentados da terra, ia alentar as aspirações da massa. E na poesia popular vinha tôda a repulsa aos antigos opressores baronistas:

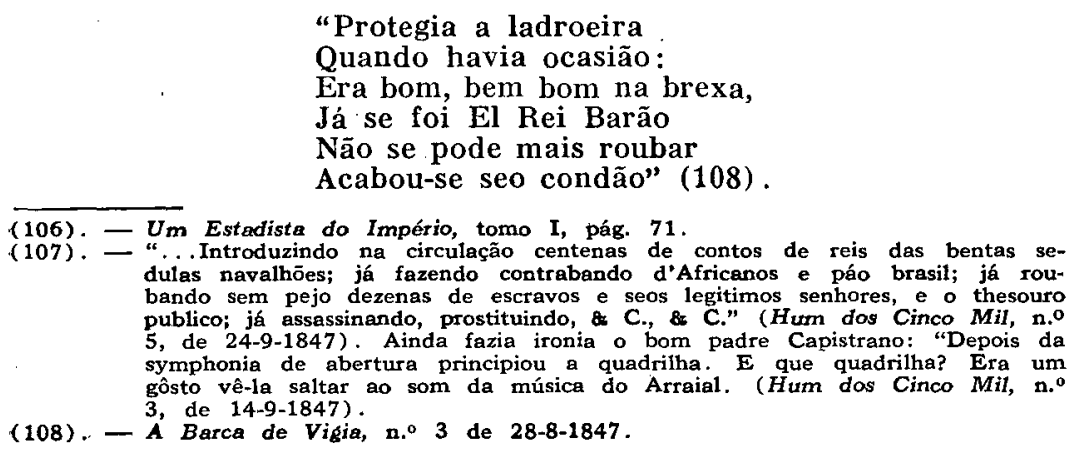


Razão teve Nabuco quando afirmou que a presidência de Chichorro "assinala o pleno domínio da Praia" (109).

Data daí o grande desenvolvimento da facção praieira e a sua reação quando, com o afastamento de Chichorro (110), ela se viu, mesmo na vigência de gabinetes liberais, em situação de ter que deixar o poder. As aspirações revolucionárias da massa não poderiam ser detidas, fàcilmente, nem mesmo pelos governantes inteiramente submissos à vontade dos guabirús, como Herculano Pena (111). Só a fôrça das armas conseguiria suster o movimento popular e trazer a vitória aos elementos reacionários. Os prenúncios da revolta, condensados nas agitações de dezembro de 1847 e junho de 1848, denotam uma turba exaltada, exacerbada nos seus instintos predatórios e onde o elemento nuclear é representado sempre pelos "valentes cinco mil" (112). Vindos das baixas camadas da população rural e urbana, os rebeldes demonstraram um grande poder combativo - um grande potencial revolucionário, como diria melhor um marxista - que nem sempre foi aproveitado hàbilmente pelos chefes. Urbano Sabino diz:

“...As forças revoltosas achavão geralmente toda a sympathia e apoio, e todo o povo espontaneamente se offerecia á -acompanha-las; nunca lhes faltavão soldados em parte alguma, e se tivessem sufficientemente armamento, terião posto em campo um exercito formidavel em relação à população pernambucana" (113).

No jornal do dr. Antônio Vicente do Nascimento Feitosa, jornal sério e doutrinário, destoando "pela sua moderação de lingua-

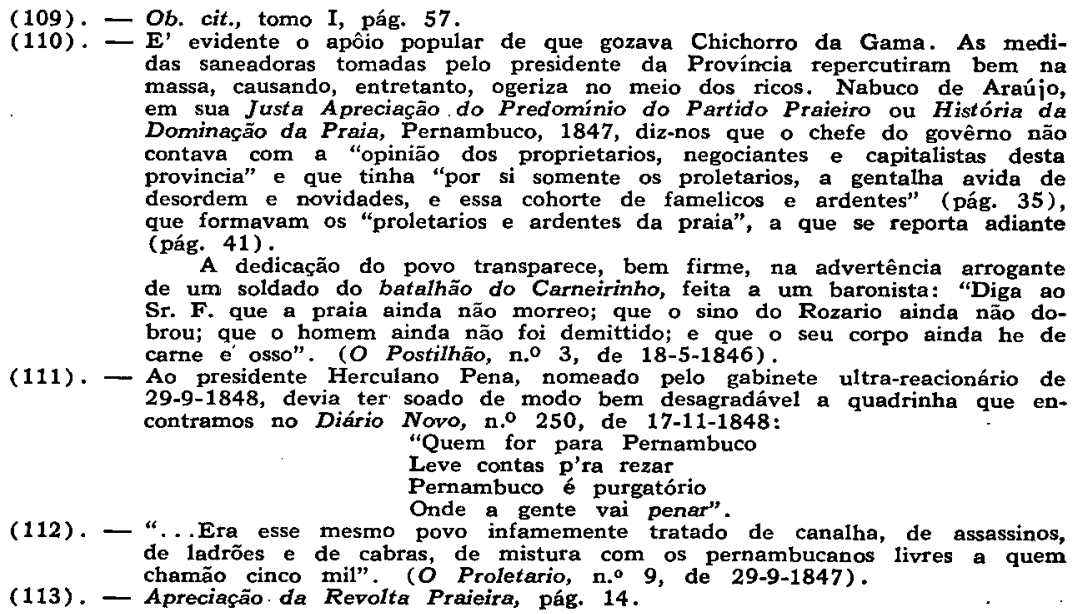
massa, causando, entretanto, ogeriza no meio dos ricos. Nabuco de Araújo, em sua Justa Apreciação do Predominio do Partido Praieiro ou História da Dominação da Praia, Pernambuco, 1847, diz-nos que o chefe do govêrno não contava com a "opinião dos proprietarios, negociantes e capitalistas desta provincia" e que tinha "por si somente os proletarios, a gentalha avida de desordem e novidades, e essa cohorte de famelicos e ardentes" (pág. 35), que formavam os "proletarios e ardentes da praia", a que se reporta adiante (pág. 41).

A dedicação do povo transparece, bem firme, na advertência arrogante de um soldado do batalhão do Carneirinho, feita a um baronista: "Diga ao Sr. F. que a praia ainda não morreo; que o sino do Rozario ainda não dobrou; que o homem ainda não foi demittido; e que o seu corpo ainda he de carne é osso". ( $O$ Postilhão, n.o 3, de 18-5-1846).

(111). - Ao presidente Herculano Pena, nomeado pelo gabinete ultra-reacionário de 29-9-1848, devia ter soado de modo bem desagradável a quadrinha que encontramos no Diário Novo, n.o 250, de 17-11-1848:

"Quem for para Pernambuco

Leve contas p'ra rezar

Pernambuco é purgatório

Onde a gente vai penar".

(112). - "...Era esse mesmo povo infamemente tratado" de canalha, de assassinos, de ladrões e de cabras, de mistura com os pernambucanos livres a quem chamão cinco mil". (O Proletario, n. ${ }^{\circ}$, de 29-9-1847).

(113). - Apreciaçáa da Revolta Praieira, pág. 14. 
gem dos contemporaneos" (114), há uma apreciação completa da influência do elemento popular na revolta e de seu aspecto social:

"Mas essas massas de ordinario são arrastadas pelos homens que dirigem o movimento; todavia cumpre confessar que as massas que adheriram ao movimento de Pernambuco se houveram com tanto heroismo, tanto valor, tanta dedicação, tanto desinteresse, que é mister que algum sentimento forte tivessem no coração, e não fosse a simples obediencia ao aceno de alguns quem os tenha á tal ponto empenhado na luta. Por certo um sentimento forte guiava essas massas, sentimento tanto mais forte quanto a questão, como dito está, era mais social que politica.

As massas que acompanharam o movimento revoltoso se compunham de homens do interior, e de homens da capital que haviam deixado suas familias e cazas para aquele fim... é pelo interior que se encontrou uma devotação praieira superior á toda a expressão, como podem informar os Srs. oficiais do exercito que por ai passaram, e essa devotação praieira não assenta tanto sobre principios de organização ministerial ou governativa, como no odio entranhavel que se consagra á esses mandões de punhal que assolam o interior da provincia. Quanto ás massas da capital, o sentimento que mais os domina é a nacionalidade do commercio, e odio á alguns estrangeiros que as tem espoliado dos meios de subsistencia" (115).

Não the foi, pois, estranho o verdadeiro sentido do movimento, o seu caráter de revolução de massa. Ainda acrescenta, mais adiante: tica".

"A questão de Pernambuco é mais social que polí-

$\mathbf{E}$, em outro número, declara que as causas da revolta

"teem um caracter social muito pronunciado e que todavia não exclue a existencia de um caracter politico" (116).

Figueira de Melo chega mesmo a traçar com perfeita nitidez o quadro completo da luta de classes, o choque entre "cavalcantis" e "cavalgados", como se tivesse em mãos o recém-publicado Manifesto Comunista:

"Como consequencia necessaria e infallivel destes manejos resultou, que a Provincia se dividisse em dous partidos; que a um delles estivessem ligados por mutua

(114). - Alfredo de Carvalho, Anais da Imprensa Periódica Pernambucana, pág. 218. (115). - $O$ Maccabeo, no 13, de 14-8-1849.

(116). - N. ${ }^{\circ} 17$, de 28-8-1849. 
attração, todos os proprietarios, negociantes e capitalistas; todas as classes illustradas; todos os primeiros Empregados da Provincia; e que ao outro, guardadas algumas excepções (quasi sempre effeito da ambição, de interesse, ou da illusão), adherissem as classes inferiores e ignorantes da população que julgando-se desherdadas dos bens sociaes, ou opprimidas por leis tyrannicas e offensivas dos seus suppostos direitos nutriam no coração os sentimentos de odio, de inveja e de vingança contra as classes superiores no mais elevado ponto de exaltação, e inspiravam assim os mais serios cuidados a quantos ouviam a sua linguagem, observavam suas aspirações, e prescrutavam no futuro as tristes consequencias, que resultariam se ellas se realisassem" (117).

\section{E ainda acrescenta que os chefes praieiros}

"prometiam às classes baixas e ignorantes da população, a posse das lojas, tabernas e boticas, que eram possuidas por Portuguezes, como recompensa de todos os seus trabalhos" (118).

Por seu lado, A União (119) caracteriza êsse aspecto da revolta:

"Entretanto, como a immensa maioria dos proprietarios, commerciantes e empregados publicos da provincia prestassem o mais decidido appoio á sabia e patriotica administração daquella epocha, e a opposição não podesse recrutar adherentes nessa parte da nossa população, a praia voltou-se, como era natural, para as classes menos abastadas e esclarecidas, e para conquistar as sympathias populares, arvorou a bandeira democratica, affagou os preconceitos das multidões; fanatizou-as com suppostas e impossiveis acusações que de continuo barateava aos seus adversários, e com certas promessas menos honrosas ainda que o cynismo com que erão propaladas e desenvolvidas".

A colaboração dos homens de côr à causa praieira é comprovada por Figueira de Mello (120), e, principalmente, a dos índios, cujo espírito combativo foi bem aproveitado para a luta, sendo recrutados nas fileiras (121), participando de modo ainda mais valioso na última fase da revolta, no chamado segundo movimento,

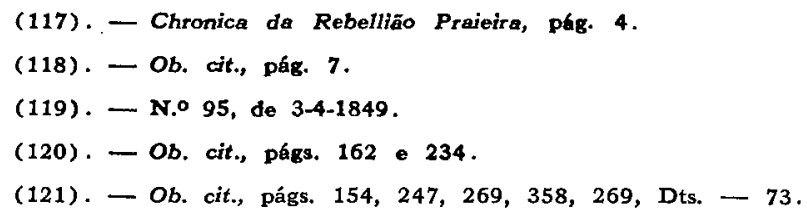


que vai de outubro de 1849 até março ou abril de 1850 (122). A participação do elemento popular e camponês é acentuada no relatório do general Coelho sôbre o ataque ao Recife, em 2-2-1849:

"Erão pouco mais de cinco horas e meia da manhã, e a cidade apresentava o espetaculo lugubre e ameaçador de uma invasão de barbaros, maltrapilhos, de camisa e ceroulas, corda e machadinha, ameaçando extirpar a classe civilizada e pacifica afeita a viver do seu honesto trabalho" (123).

Por sua vez, o general Mello Rego, testemunha que foi da revolta, diz; referindo-se aos assaltantes do Recife:

"Estes, em geral, homens de campo, descalços, matutos como lá chamam, não conheciam em sua maioria as ruas da cidade, e alguns até nunca tinham ido á ella" (124) .

$\mathbf{E}$, mais além, afirma:

"Desordenadamente, mas corajosamente, batiam-se aquelles pobres matutos sem commando e sem guia: morriam matando" (125) .

De outro lado, do lado dos Cavalcantis, encontrava-se a gente do partido da "Ordem", em contraposição aos "mulambos" (126), dêsse partido da Ordem que, através da nossa História, tem dominado a nossa vida política e econômica, cumpliciando-se com todos. os reacionarismos, com todos os fascismos ostensivos ou velados. Era o partido dos ricos proprietários, dos senhores de engenho, dos. negociantes abastados (127), aquêle

\footnotetext{
(122). - O General Mello Rego (Rebellião Praieira) considera êste último movimento inteiramente despido de sentido político, simples manifestação de anarquia. Entretanto, o próprio Honório Hermeto Carneiro Leão, que, inicialmente tinha essa idéia, retificou-a, por completo, como diz no ofício dirigido ao. chefe de policia interino, mandando-o proceder à formaçăo da culpa dos implicados (Ver sumário-crime instaurado. MS in Inst. Hist. Geo. Pernambucano). Lançaram os rebeldes um manifesto que foi publicado no jornal. O Século e há duas cartas de Miguel Afonso Ferreira, uma a Pedro Ivo e outra a João do Rego Barros Falcão, onde encontramos referências claras ao caráter político da revolta (ver referidos documentos no acima citado sumário-crime). Os depoimentos das testemunhas ouvidas são unânimes na afirmação de que os revoltosos de Pedro Ivo continuavam com a mesma bandeira da Praia: a convocação de uma constituinte. Sendo que a $4 a$. testemunha, João Damasceno Pacheco afirmou ainda que "sabia por ouvir dizer e ser notório, que os rebeldes queriāo era huma Constituinte para reformar a Constituição do Império, e outros a republica" (ver sumário-crime).

(123). - Apud Urbano Sabino, ob. cit., pág. 313.

(124). - Rebellião Praieira, pág. 227.

(125). - Ob. cit., pág. 228.

(126). - "Estão os praieiros divididos em Cachorristas, Mulambistas e Elefantiatas... 0 cegundo compōe-se de esfaimados ( $O$ Postithão, n.o 10 de 18-7-1846).

(127). - Referindo-se ao tempo em que o partido da Ordem - durante o govêrno de Chichorro de Gama - esteve no ostracismo, diz A Carranca, n.0 18, de 10-71847: ". . a opposição de Pernambuco năo era causa de família: pois contava em suss fileiras toda a população crada, mais rica e industriosa da provincia".
} 
"em cujas fileiras se acharam alistados os filhos dos. mais ricos proprietários" (128) .
\end{abstract}

Facção estruturamente reacionária foi bem representada por Vieira Tosta, o futuro Muritiba, cujo espírito intensamente conservador é destacado pelo retrato que lhe pintou Nabuco:

"Tosta era um conservador dos raros que tinha a religião, a monarchia, a ordem publica, a lei, como dogmas indiscutíveis. Intolerante, quando se tratava delles; exclusivista, no sentido de julgar impróprio para as fun-. ções do Estado quem os não professava, elle confessadamente o era" (129).

Quando em 1866 se discutiu, no Conselho de Estado, sôbre o. projeto emancipacionista de Pimenta Bueno é sintomático ter Viei-. ra Tosta votado contra a sua aprovação, sendo sòmente acompanhado pelo ultra-reacionário marquês de Olinda, o chefe do gabinete de 29-9-1848, que debelou a Praieira (130). E, ainda como outro vulto representativo da facção, temos o general José Joaquim Coelho, cuja biografia traçada pelo $O$ Constituicional, de 23-1-1842, nos mostra o português inculto e boçal, que, por uma dessas reviravoltas do destino, explicável sòmente pelo muito de sabujice e de vilania que the ia n'alma, chegou a ser general do exército bra'sileiro, embora, no fundo, continuasse o mesmo ignorante de outrora, agravado, agora, pelas atitudes de chefe atrabiliário e prepotente. O bárbaro assassino do coronel Facundo no Ceará, estava, naturalmente, indicado a ser o braço escolhido para defender a Ordem, a mesma Ordem dos potentados e dos opressores, que queriam continuar, na província de Pernambuco, o seu domínio de latifundiários e de senhores feudais.

O insucesso da revolta é uma resultante da deficiente organização revolucionária da massa. O potencial revolucionário do povo não foi bem aproveitado. Insuflou-se o elemento popular contra a opressão dos Cavalcantis e dos estrangeiros, mas não se soube orientá-lo, quando chegou o momento adeqüado à conquista do poder. Antes, muitos tiveram até receio das suas manifestações avançadas. de reivindicação social. O próprio Diário Novo protestou contra. - Manifesto ao Mundo. Os chefes, mal preparados, quase todos, tècnicamente, para a revolução, dotados de conhecimentos militares. insuficientes, exceto um Pedro Ivo, não bem afeitos à tática de luta de ruas ou de guerrilhas, não puderam dirigir aquela massa popular

\footnotetext{
(128) . - Figueira de Mello, ob. cit., pág. 127, assim como págs. 94, 99, 114, 200, 206,. 357 e 372 .

(129). - Ob. cit., tomo I, pág. 70.

(130): - Ver Rio Branco, Ephemérides Brasileiras, pág. 69.
} 
que teria provocado, sob a direção de hábeis líderes; a conquista do Recife e da Província, e quem sabe lá que conseqüências nacionais adviriam daí... (131). Mas os seus líderes não conheciam, em sua quase totalidade, os princípios da técnica do golpe de Estado. Não estavam a par das lições dos grandes teóricos do marxismo sôbre os combates de rua e sôbre as atividades de partizans (132), ou dos ensinamentos de Cúrcio Malaparte sôbre a tomada do poder (133). Dois chefes encontramos, capazes de dirigir eficientemente o movimento, um quanto à direção militar, e outro quanto à direção política: Pedro Ivo e Borges da Fonseca. Mas foram anulados pela ação da maioria liderante. Militarmente falando, mostrou Pedro Ivo qualidades apreciáveis. Embora discordando do plano do ataque ao Recife, em virtude da precariedade de meios, de que dispunham os revoltosos, ainda assim realizou um notável feito de armas com o seu movimento de flanco, burlando completamente o general Coelho. Eis o que afirma uma testemunha dos fatos e que, por sinal, não é nada simpática aos praieiros em geral e a Pedro Ivo em particular:

"Esse movimento de flanco, quando do Rio Formoso já o general Coelho (Barão da Vitória) tinha posto em marcha as suas avançadas para atacar os rebeldes naquelle ponto, foi sem duvida admiravel, pela sua concepção, como pela exactidão e presteza com que foi executado, e bastaria para formar a reputação de um general em qualquer terra regular"' (134).

E ainda acrescenta:

"Só quem conhece a topographia da região atravessada por aquella força, que de mais a mais, para esconder a sua marcha, teve de procurar caminhos desconhecidos, quasi impraticaveis, com voltas e desvios, para não se encontrar com as forças do Governo, sob o sol abrazador de janeiro, tendo de transpor extensões que na-

(131). - Se não tivesse sido o mau sucesso de 2 de fevereiro, com a morte de um dos chefes de maior prestígio, com certeza o movimento se teria propagado ràpidamente, pela Paraíba (Ver Lyra Tavares, Estudo sobre a Rebellião Praieira, págs. 63 e 68 e M. L. M., Quadro da Revolta Praieira na Provincia de Parahyba, Pernambuco, 1851). Quanto às Alagoas mesmo depois do mau êxito do ataque ao Recife, ainda perdurava, no seio das autoridades, um certo temor de prováveis agitacōes. $E$ ' o que se aquilata do seguinte ofício, dirigido ao Presidente da Província de Pernambuco, Manuel Vieira Tosta: "Ilmo. e Exmo. Snr. Tornando-se de urgencia para o serviço publico que um navio de guerra estacione no porto desta Cidade, rogo a V. Excia. que se digne ordenar a vinda para este fim de algum dos que se achão nessa Provincia.

Deos Guarde a V. Excia. Palacio do Governo em Maceió 16 de Fevereiro de 1849. O Presidente - Antonio Nunes de Aguiar". (MS in Arquivo do Estado de Pernambuco)

(132). - Ver La Lucha de Guerrilhas a la luz de los clasicos del Marrismo-Leninismo, Instituto Marx-Engels-Lenin, Bs. Aires, 1945.

(133). - Ver Tecnica del Golpe de Estado.

(134): - General Mello Rego, Rebeliāo Praieira, págs. 37 e 38. 
quelle tempo eram pouco menos que deserto, em que até agua para beber faltava, é que pode avaliar o esforço empregado, para vencer as difficuldades que se oppunham a semelhante operação e a pericia com que foi esta executada" (135).

A autoria dessa admirável operação é, sem nenhuma dúvida, de Pedro Ivo, como se observa pela própria afrimação do comandante das tropas legais:

"A Peixoto de Brito, como general em chefe, deve caber a gloria desse feito. Mas o general Coelho dizia que só a Pedro Ivo é que se devia atribuil-a" (136).

$O$ ataque à cidade não foi realizado, de acôrdo com as idéias de Pedro Ivo, que planejou investí-la com um só coluna, o que teria, certamente, contribuído para um rápido êxito, antes que chegasse o general Coelho, então no Sul da Província. Mas os comandantes preferiram atingí-la com duas colunas, uma por São José e outra pela Soledade, o que redundou num mau sucesso. Faltou ligação entre os dois corpos, faltou unidade de comando, e, enquanto uma conseguia certo resultado satisfatório, a outra, inexplicàvelmente, ficou detida na Soledade. O desconhecimento da topografia da cidade pelos combatentes - quase todos do interior, camponeses ignorantes da distribuição das ruas do Recife, perdendo-se no emaranhado delas, desambientados, assim, para sustentar uma luta em ruelas e becos inteiramente desconhecidos para êles (137) - foi uma das causas da coluna de Pedro Ivo não ter logrado bom sucesso. Mas, muito embora a derrota, admiração nos causa o modo como o grande chefe praieiro conseguiu escapar com vários de seus comandados, não obstante a chegada do futuro barão da Vitória, e ainda realizar uma hábil retirada sem ser molestado. E a capacidade militar de Pedro Ivo ainda deve ser salientada quando, ao separar-se da coluna do Norte, seguiu em direção ao Sul da Província, efetuando um habilíssimo movimento, mesmo nas barbas dos governistas, o que foi reputado pelo General Mello Rego como

"uma operação audaciosa realizada com pericia"

Há também, a projetar-se no cenário da revolta, uma figura que não foi ainda bem estudada e bem destacada pelos historiado-

(135): - Ob. cit., pág. 38.

(136). - General Mello Rego, ob. cit., pág. 38.

(137): - Ver General Mello Rego, ob. cit., págs. 227 e 228.

(138). - Ob. cit., pág. 119 . 
res da Praieira, figura que merece uma apreciação particular e que está exigindo dos investigadores da nossa história política e social um ensaio de interpretação biográfica, situando-se na posição que merecidamente lhe compete dentro da nossa evolução histórica, aliás, de uma das fases mais agitadas e mais brilhantes da nossa evolução histórica. Refiro-me ao tribuno popular e jornalista, ao condottiere de idéias republicanas e sociais que foi o paraibano Antônio Borges da Fonseca - o célebre Repúblico. Que se manifestem os Gilberto Freyre, os Olívio Montenegro, os Otávio Tarquinio, os Sílvio Rabelo, os Caio Prado, os Pedro Calmon sôbre assunto tão palpitante e tão vasto e que não se enquadra nos moldes limitados de uma tese. Há pouco, é verdade, o sr. Hélio Vianna apresentou uma contribuição valiosa ao estudo do vulto de Borges da Fonseca, mas pelo sentido especializado que imprimiu à sua obra, o seu trabalho adstringe-se, ùnicamente, à figura do jornalista, por sinal, um dos mais férteis e dos mais combativos na História do jornalismo brasileiro (139). Continua a impor-se, assim, um estudo de maior porte, um ensaio onde os vários aspectos da vida de Borges da Fonseca sejam apreciados nos seus variados pormenores e situados no seu tempo.

A personalidade do "Repúblico" é daquelas que não se limitam a um reduzido momento histórico. A sua projeção se manifesta por um vasto período do nosso passado. Os primeiros anos de sua vida não são bem conhecidos. Estudante no Seminário de Olinda (140) e no Liceu, onde foi contemporâneo de Paula Batista (141) pouco se sabe em relação a essa fase de sua existência. O documento mais importante para o conhecimento de suas aventuras, o seu Manifesto Político (142), é pouco minucioso nessa parte. A sua atividade inicia-se $\operatorname{com} \boldsymbol{A}$ Gazeta Paraibana e não mais sofre grandes interrupções até a sua morte. Jornalista destemido, tornou-se célebre pelo grande número de jornais que dirigiu, imprimindo em todos a marca de seu temperamento irrequieto e rebelado. As preocupações políticas o assediaram desde o início. Desde o princípio, que o vamos encontrar atuando em sociedades secretas, numa ânsia incontida de melhorar a situação do país. Membro da Jardineira ou Carpinteiros de S. José, quando acesa era a luta contra o absolutismo, abrigado na Sociedade Coluna do Trono e do Altar, vemo-lo depois na direção da Vigilante, ao lado do padre Luiz Ignacio de Andrade Lima (143). E ainda depois na Popular (144). O período que vai da Abdicação às últimas ma-

(139). - Ver Hélio Vianna, Contriburição à História de Imprensa Brasileira, Rio, 1945.

(140): - Hélio Vianna, ob.cit., pág. 536.

(141). - Olivio Montenegro, Memórias do Ginásio Pernambucano, pág. 21.

(142): - Recife, 1867.

(143). - Ver Pereira da Costa, Anais Pernambucanas.

(144). - Ver Nabuco,' ob. cit., tomo I, pág: 277. 
nifestações da Praieira é, talvez, o mais agitado da sua agitadíssima: vida de tribuno do povo, sempre em luta com os poderosos. Mas não foram sòmente as preocupações políticas que lhe impressionaram o espírito de eterno rebelado contra as injustiças. Sobretudo as idéias de reivindicação social, de reforma de uma sociedade firmada num patriarcalismo de senhores de engenho todo-poderosos,

- num exclusivismo de famílias dominadoras, aliadas a elementos. alienígenas, monopolizadores das fontes econômicas da província, levaram-no a ser, dentro do ambiente social do Império, uma espécie de Quixote a batalhar contra os moinhos de vento do mais completo e opressivo reacionarismo. O sentimento de solidariedade humana dêsse Rienzi Brasileiro, a imaginar-se "investido de uma espécie de realeza tribunícia" (145), transparece em tôda a sua. vida. Vemos sempre nele a preocupação pelos que sofrem injustiça, pelos explorados e pelos humildes. Há no Diário Novo (146) o seguinte anúncio:

"O abaixo assignado se acha estabelecido na rua da. Penha casa $n .^{\circ} 5$; onde igualmente tem estabelecido $a$. typographia social nazarena; pretende advogar, principalmente no crime; aquelles que se quizerem utilizar de seu prestimo o podem procurar nos dias uteis: offerece-se tambem a todos os miseraveis, e aquelles que sofrerem prepontencias, e não poderem promover seu direito, 0 que fará gratuitamente. Antonio Borges da Fonseca".

Em permanente luta contra o despotismo, batendo-se em constante defesa dos ideais democráticos, que êle, em plena monarquia, identificara com o sistema republicano (147), êste homem que $\mathrm{Na}$ buco considerou "um revolucionário em disponibilidade" figura

(145). - Joaquim Nabuco, ob. cit., tomo I, pág. 277.

(146). - N.0 175, de 14-8-1844.

(147). - Foi bem intensa a expansão das idéias republicanas e federativas no período preparatório da Praieira. Com jornais entusiastas e combativos ia o grupo republicano encontrando ambiente favorável em uma província tradicionalmente anti-monárquica. Os exemplos de 1817 e 1824 estavam bem vivos. E se o movimento da Praia tivesse se prolongado mais tempo teria agido, como agiram os farrapos no Rio Grande, desfraldando às claras, o estandarte da República. Aliás, essas tendências republicanas ou democráticas como eram também denominadas, estavam ligadas às mais avançadas manifestações de refórmas social. O Nazareno era o seu mais ardoroso arauto, tanto que, com o tempo, os seus adeptos ficaram conhecidos pelo nome do jornal. Contra êste pensamento avançado $A$ Ratoeira $\left(n .^{\circ} 1\right.$ e único de $\left.3-9-1847\right)$, com todo o seu reacionarismo bien pensant, bradava: "Democracia em Pernambuco! democracia no Brasil! Mas com que elementos, com que meios, com que gente se há de estabelecer entre nós esta forma de governo; aliás admirável quando he adoptado por hum povo illustrado e de bons costumes? $\mathrm{Na}$ verdade só huma cabecinha de camarão, como a de Borges da Fonseca conceberá a exequibilidade d'huma democracia no Brasil, paiz essencialmente aristocratico, composto de classes' tão heterogeneas, paiz onde até os mais pronunciados liberalöes trafícão em carne humana! Entre nós o branco ou o que nesta conta se tem quer passar por fidalgo, e julga-se superior ao pardo; o pardo não quer hombrear com o cabra; o cabra olha sobranceiro para o . preto; o creoulo não soffre que o ponhão a par do africano, o liberto julga-se muito acima do escravo; além disso he quasi universal a nôssa paixão por titulos, por comendas, por. 
"na galeria dos nossos tribunos republicanos como o que mais distintamente possuiu a envergadura revolucionária" (148).

Há na sua atividade vislumbres de aspirações de líder socialista:

"Quizesse Deos dar-me talento para ao menos imitar o procedimento desses sabios e generosos chefes da republica vermelha, fora isto dar-me conhecimento dessas vastas theorias, que em menos de um seculo vão regenerar a Europa. Um seculo a datar de 1780" (149).

O que se sente na alma do "Repúblico" é o desêjo sincero de acompanhar as reivindicações populares, sem interessar-lhe o título dos partidos políticos. Esteve contra Chichorro da Gama por julgar que sòmente o 'seu republicanismo exaltado resolveria os problemas do momento. $\mathrm{Na}$ ocasião, entretanto, em que a Praia foi, verdadeiramente impelida pela eclosão dos impulsos populares e se atirou à revolta, visando abater à prepotência dos guabirús, Borges da Fonseca, fiel ao seu passado de luta, não trepidou em unir-se aos inimigos da véspera. Explica êle a sua atitude, no Diário Novo:

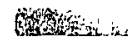

"Alguem houve, que me conhecendo, e sabendo perfeitamente qual a minha missão, me procurara para pedir-me de ficar neutro no litigio que estava aberto entre

condecoraçōes, por habitos: e com tal população, como he possivel estabelecer governos democráticos?" E termina prevenindo os baronistas quanto aos perigos de sua aliança com os nazarenos:

"Democracia entre nós

Guabirús he forte asneira,

Não vos façaes infelizes,

Não caiaes na ratoeira".

Um núcleo onde as idéias reformadoras e republicanas encontraram boas possibilidades de repercussão foi a Academia de Direito de Olinda. Os asadêmicos chegaram a lançar um manifesto dirigido aos estudantes republicanos das Universidades da França, da Alemanha e da Itália de adesāo aos seus princípios (ver $O$ Grito da Pátria, n. ${ }^{\circ} 6$, de 5-8-1848). Esse mesmo jornal no seu n.o 13 de 18-11-1848, com a revolta já começada e em franco progresso, comenta: "Todos os estudantes das universidade da Europa, e da briosa academia da cidade de Olinda, nossa patria, tão bella, e idolotrada, teem manifestado, o maior enthusiasmo pelo triumpho das ideias Republicanas; só os es tudantes da academia jurídica de S. Paulo vivem abysmados nas illusões, e depravado servilismo da corte". E parece que, pouco antes de começar o movimento da Praia, houve qualquer agitação nos meios estudantis de Olinda. Pelo menos é o que se percebe do seguinte oficio: "Cumpre-me dizer á $V$. Ex., que esta capital e a cidade d'Olinda permanecem tranquillas, não devendo recear-se a continuação dos sustos, e d'algumas noticias exageradas, e infundadas, que se tem espalhado de perseguição á alguns Academicos, attentas as pesquizas, e informaçôes, que colhi com a minha hida á dita cidade, e depois dáqual nenhuma queixa, e reclamação tem apparecido da parte dos mesmos Academicos. Deos Guarde a V. Exa. Secretaria da Policia de Pernambuco 18 de Outubro de 1848. - Ilmo. e Exmo. Snr. Commendador Herculano Ferreira Penna, Presidente da. Provincia. Firmino Antonio de Souza, Chefe de Policia. (MS in Arquivo Público do Estado de Pernambuco).

(148). - Ob. cit., tomo I, págs. 272 e 278.

(149): - Carta ao padre Joaquim Pinto de Campos, in Diário Novo, n, ${ }^{\circ} 48$ de 31-7-1849. 
a praia e os guabirús, pois que era necessario ensinar aquella; e apesar de meus desgostos, lembrei a esse, minha missẫo era chorar com os que chorassem, estar sempre da parte do fraco, ser contra o opressor... pois que não me faria em tempo algum cumplice da tyrannia" (150).

Diria êle hoje, certamente, usando uma linguagem de sabor marxista, que não tinha compromissos senão com o povo, seguindo o pensamento que fixara em $\boldsymbol{A}$ Mentira (151):

"Praia, guabirú, saquarema, tudo isso he chimerico, só he real o Brasil". "Panfletário terrivel foi, sobretudo, nos seus pasquins (152) que o mais fecundo dos nossos. jornalistas políticos",

no dizer de Alfredo de Carvalho, maior influência exerceu no agitado período de preparação da Praieira.

Entrado tardiamente no movimento praieiro, pois até então, estivera afastado do choque entre as duas facções inimigas, fiel aos seus princípios republicanos e às aspirações de reforma social, tornou-se, entretanto, depois, um dos líderes mais salientes, e, quiçá, o único a poder dirigir a revolta armada, com possibilidades de êxito, e com possibilidades de fixar um conteúdo doutrinário sólido. Herculano Pena tentou, temeroso, talvez, de sua capacidade admirável de condutor de massas, obter a sua neutralidade no conflito entre a Praia e os guabirús, mas Borges da Fonseca, o eterno revolucionário em potencial (153), vendo no momento uma oportunidade para a vitória de seus ideais, entrou ardorosamente na revolta, em 15 de novembro (154), embora a tivesse considerado

(150). - De uma carta a Maciel Monteiro, in n. 31 de 12-7-1849.

(151). - N.O 2, de 24-7-1848.

(152). - Foi grande a ação dos pasquins no desenvolvimento de nossa vida política. Nabuco bem lhe acentuou a importancia: " $O$ pasquim exerceu consideravel influencia em nossa politica e foi um dos principais instrumentos de sua prom funda democratização". (Ob. cit., tomo I, pág. 277).

(153). - "Dotado de alguma intelligencia e coragem; acostumado desde a sua moci dade a planear desordens, resistencias e revoluçōes, que pareciam terem-se tornado um elemento de sua irrequieta existencia" (Figueira de Mello, ob. cit.; pág. 394).

(154). - "Assirn estava aberta a lucta entre o poder corruptor do Brasil e o povo; e eu entendi dever abandonar minha familia, meus commodos, as vantagens de um Advogado, que cosava já de créditos seguros, para tomar parte na lucta: contra o poder, em fovor do povo, e minha consciencia me accusaria, se nảo procedesse assim, se sem meu compromettimento fosse o povo vencido. Sahi pois de minha casa na Cidade do Recife no dia 15 de novembro; vim a Iguarassú, reuni 60 paisanos armados; deixei-os em ponto; parti para o Catucá; achamos Moraes e João Paulo, os quaes acceitaram o meu convite, e assim se organisou a columna liberal do Norte, que tanto fez em prol da causa. Fomos sempre perseguidos pelo Governo, á quem só dá cuidado a columne liberal do Norte". (Do manifesto de Borges da Fonseca de 27 de março de 1849, in Figueira de Mello, ob. cit., págs. 386 e 387 e Lyra Tavares, Estudo sobre a Rebellião Praieira, págs, 79 e 80 ). Antes da revolta já $A$ Mentira (n.o 1, de 17-7-1848) acentuava a importância de sua atuação revolucionária: ". . he aquelle a quem mais temem as facçōes por cuja causa o atrocidam". 
"prematura, por nem termos munição de guerra, e nem ao menos o accordo da Parahyba e Alagôas; façamos munição, e escrevamos aos amigos das duas Provincias" (155).

Viu a possibilidade de imprimir a um movimento que sentia ter tendência popular, embora disperso e sem uma diretriz firmada, um programa onde predominassem as suas velhas e avançadas reivindicações. $E$, em verdade, as linhas mestras fixadas no Manifesto ao Mundo, que serviram de bandeira à rebelião, foram de sua autoria. As suas antigas pretensões de velho discipulo do socialismo utópico dos revolucionários de fevereiro na França (156), foram tornar-se o estandarte dos praieiros, e, ironia do destino, defendidas por aquêles mesmos políticos que as tinham atacado anteriormente. Parece mesmo que sentiu a possibilidade de orientar os trabalhos da sonhada Constituinte. Pelo menos Figueira de Mello refere-se à

$$
\begin{aligned}
& \text { "inauguração de uma Constituinte presidida e diri- } \\
& \text { gida por Borges da Fonseca", }
\end{aligned}
$$

como um dos alvos dos chefes rebeldes (157).

Com a morte de Nunes Machado, ter-se-ia extinguido, por completo, a revolta, se "O Repúblico" não a continuasse a dirigir. Foi o guia ardoroso e entusiasta do movimento da Praia, depois do 2 de fevereiro. E, apesar das defecções, mostrou, durante tôda a luta, uma fortaleza de ânimo, que não encontramos, exceto, talvez, em Pedro Ivo, em nenhum outro chefe. Os seus companheiros, muitas vêzes, desiludidos e quebrantados, não o abandonavam, pelo temor, pelo receio, que lhes inspiravam a sua indomável bravura e a sua firmeza de propósitos. Ouçamos, a respeito, Figueira de Mello:

“...Era esse caudilho depois da morte do Desembargador Nunes Machado, a cabeça que dirigia a revolta, e o braço que a sustentava, o Chefe enfim que se punha á frente dos combatentes. Os outros Chefes da rebeldia seguiam quasi sempre a sua opinião; tinham tanta confianca nelle, que o fizeram Commandante da colunna, que atacou a Cidade pelo Sul; e finalmente temiam

\footnotetext{
(155). - Do manifesto de 27-3-1849, in Figueira de Mello, ob. cit., pág. 386 e Lyra 'Tavares, Estudo sobre a Rebellião Praieira, pág. 79.

(156). - Diz Figueira de Mello: "enfarinhado nas doutrinas inexequiveis de escriptores demagogicos, desde Rousseau até Cabet, que tinha por oraculos; pertinaz sobre modo em sustental-as pela imprensa, e pela palavra entre as classes baixas da Sociedade, unicas que por sua ignorancia podiam recebel-as sem contradicção, e á quem fallava sempre $\mathrm{em}$ estylo rasteiro e apaixonado ao mesmo tempo; tendo extraordinaria obstinação em seus planos de proclamar o Governo Republicano, a qual parecia augmentar-se pelos trabalhos, que tinha soffrido, desde que entrára na carreira politica". (Ob. cit., pág. 394)

(157). - Ob. cit., pág. 327 .
} 
tanto os seus excessos, que alguns se quizeram deixar as armas, tiveram necessidade de atraiçoal-o. Quantos ás massas populares, estas deixavam-se arrastar pela sua energia de mando, ao som das palavras de liberdade, que elle lhes dirigia e pelos terrores de captiveiro que lhes incutia para affastal-os da causa da ordem e da lei" (158).

As suas qualidades de chefe enérgico, de líder revolucionário previdente e audaz, de autêntico condutor de massas, são acentuadas por todos os que interessaram pela revolta da Praia. O general Mello Rego dêle nos pinta êste retrato:

"Figura antipathica, magro, escaveirado, physionomia simiesca, oculos fixos, ardente ate a ferocidade, timbre de voz agudo e aspero, tinha, entretanto, palavra fácil, animada e persuasiva, sobretudo dirigindo-se ás classes pouco illustradas. Sabia incutir-lhes no animo o que sentia ou apparentava sentir, pois a sua linguagem amoldava-se sempre às circunstancias da occasião" (159).

Quando aprisionado e reconduzido ao Recife, soube portar-se com muita dignidade e estoicismo, não obstante tôda a ostentação de que foi cercada a sua entrada, demonstração evidente da importância de sua captura e desafôgo das autoridades (160). Maximiano Lopes Machado, mostrando-nos o descaso dos revolucionários paraibanos na defesa de Areia, excetua

"o cidadão Antonio Borges da Fonseca que com poucos mais tratava de prevenir, bem que tarde fosse, alguma surpresa desastrosa" (161),

o que evidencia, uma vez mais o seu senso arguto de chefe. E' pena que o jornalista do Nazareno não tivesse, desde o comêço, participado da preparação da revolta. Ingresso no movimento já depois dêle iniciado, não teve elementos, embora os seus evidentes méritos de guia do povo, para encaminhar os acontecimentos. 0 ardente polemista de $O$ Tribuno (162) não poderia inspirar grande confiança aos seus antigos adversários políticos, não obstante ter sido indicado para um posto de destaque. Mas, depois, quando com o mau sucesso do ataque ao Recife e a morte de Nunes Machado, tudo parecia perdido, foi em Borges da Fonseca que se concentrou todo o ardor, tôda a combatividade da rebelião da Praia. Chefian-

(158). - Ob. cit., págs. 394 e 395.

(159). - $O b$, cit., pág. 29. Ver também sôbre o assunto págs. 79 e 93.

(160). - Ao lado do capitão Soledade e acompanhado por 80 praças do 8.0 batalhão de caçadores, Borges da Fonseca, calmo e de 'cabeça erguida (fôsse por altivez natural ou pelo hábito que adquirem os que usam óculos fixos), mirando serenamente a um e outro lado, não parecia um prisioneiro". (Mello Rego, ob. cit., pág. 94 )

(161). - Quadro da Revolta Praieira na Província da Parahyba, pág. 155.

(162). - O Eco Pernambutcano (n." 2, de 12-1-1855) chama-o de "decano dos republicanos do Brasil e apostolo da democracia". 
do-a, êle, o líder popular, impetuoso e bravio, prolongou-a, mantendo sempre a esperança de receber auxílio e conquistar a vitória. Se tivesse, em posição de comando, atuado no partido praieiro, antes do apêlo às armas, outra teria sido, certamente, a diretriz do movimento.

Bem afirmou Lyra Tavares que já

"é tempo de serem rebatidos os conceitos apaixonados e injustos com que procuraram encobrir os meritos inconfundiveis de Borges da Fonseca" (163).

E nenhum julgamento sôbre a sua gigantesca figura é mais valioso que o do general Mello Rego:

"Em sua vida publica, que talvez nenhum outro Brazileiro a tenha tido mais movimentada, acham-se actos de verdadeira abnegação, e como que dictados unicamente por patriotismo, bem ou mal orientado.

De par com os seus grandes defeitos, com um quid subversivo, destruidor, perverso, que em momento dado irrompia do seu animo ardente, como uma lava inflamada, que faltavam-lhe forças para conter, tinha qualidades apreciaveis pouco communs" (164).

Possuidor de idéias firmadas há anos e cada vez mais consolidadas com o tempo e os reveses, inspirador de um programa doutrinário para um movimento que trazia em si subterrâneas manifestações de impulsos populares, em busca de reivindicações imprecisas, desprezadas, talvez, não obstante inicialmente acalentadas pelos seus incitadores politicos, vê-se em Borges da Fonseca o eterno batalhador em busca de um mundo melhor, o eterno defensor dos fracos e dos oprimidos, e o verdadeiro fixador de um conteúdo de idéias para o programa da Praieira. Disse êle, sintetizando todo o espírito da revolta:

"Nossa guerra é social (165). Deve ter sentido como poucos o desejo de tornar uma realidade o pensamento de Chateaubriand, reproduzido em $O$ Progresso (166) e lido, certamente, com sofreguidão por aquela alma entusiasta e arrebatada, voltada sempre para os grandes empreendimentos: "Un temps viendra ou l'on ne concevra pas qu'il fut un ordre social dans lequel un homme comptait un million de revenu, tandis qu'un autre homme n'avait pas de quoi payer son diner. Un noble marquis et un

\footnotetext{
(163). - Ob. cit., pág. 82 .

(164): - Ob. cit., pág. 91 .

(165). - Trecho de uma carta de Borges da Fonseca a Vieira Tosta, em Figueira de Mello, ob. cit. Apêndice, pág. 133.

(166). - Tomo III, págs. 56 e 59.
} 
gros proprietaire paraitront des personnages fabuleux, des êtres de raison" (167).

O "Repúblico" que na sua vida agitada de tribuno do povo, de condutor de homens, abrigara, como nenhum outro, o sentimento de solidariedade humana, não iria perder a oportunidade de impelir um movimento que nascera, aparentemente, de competições políticas, para uma tendência de reforma social. E é essa uma das glórias de Borges da Fonseca. Fazer das reivindicações populares dos cavalgados, vítimas de um sistema econômico, alicerçado na mais torpe exploração do homem, exercida por uma minoria de grande proprietários, o panache de uma das mais belas e mais impetuosas explosões de massa na nossa história político-social, que foi a Revolução Praieira.

\title{
AMARO QUINTAS.
}

\begin{abstract}
(167). - Foi sempre o polemista do Nazareno um ardoroso combatente das boas causas. Conta-nos o sr. Hélio Vianna que êle não esquecia os feitos e os homens das campanhas liberais: "Assim, a 2 de fevereiro mandava rezar missa pelos mortos na revolta praieira. A 6 de março, evocava a revoluçäo pernambucana de 1817. A 25 do mesmo mês, lamentava a "defunta", isto é, a Constituição de 1824 . E assim por diante. Antigos revolucionários, como o Tiradentes, o Coronel José de Barros Falcão de Lacerda Cavalcanti de Albuquerque, da Confederação do Equador, Bento Gonçalves da Silva, Eduardo Fran. cisco Nogueira Angelim, da cabanagem do Pará (seu companheiro de prisão, em Fernando de Noronha, como Fracisco Pedro Vinagre, no Recife) - mereciam-lhe necrológios, lembranças ou elogios". (Ob. cit., págs. 584 e 585 ). Adversário tenaz da política imperial no Prata, mostrou-se hostil à guerra contra o Paraguai, chegando mesmo a lembrar um protesto contra a luta "filha do capricho, da injustiça, da iniquidade". ( $O$ Tribuno, de 20-9-1867). Continuava a defender o "direito á vida material, á vida intelectual e moral, á liberdade, á soberania", achando que o pretenso principio igualitário oriundo do liberalismo da Revolução Francesa, permanecia como uma doce ilusão, fazendo-se mister uma reforme ampla da sociedade: "A igualdade não existe, onde ha uma raça d'omens que comande sempre e outras raças d'omens que obedeçam sempre. (O Nazareno, Diário da Tarde, n. ${ }^{\circ} 2$, de 9-6-1848). Precursor, assim, das mais modernas tendências de democracia social.
\end{abstract}

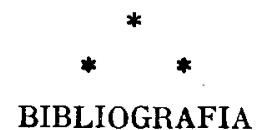

Figueira de Mello - Chronica da Rebelliâo Praieira. Rio, 1850.

Urbano Sabino Pessoa de Mello - Apreciaçâo da Revolta Praieira em Pernambuco, Rio, 1849.

M. L. M. - Quadro da Revolta Praieira na Provincia da Parahyba, Pernambuco, 1851.

General Mello Rego - Esboço Biographico do Conselheiro Senador do Imperio Antonio Pinto Chichorro da Gama. Typographia Industrial, rua do Imperador, 75, Recife, 1887.

Nabuco de Araujo - Justa Apreciaçâo do Predominio do Partido Praieiro ou Historia da Dominação da Praia, Pernambuco, na Typographia União, 1847.

Nabuco de Araujo - As eleiçóes para senadores na provincia de Pernambuco em 1847. Pernambuco, 1848. 
Joaquim Nabuco - Um Estadista do Imperio: (2 vols.), São Paulo, 1936 .

Abreu e Lima - o Socialismo, Recife, 1855.

Folhinha de Algibeira ou Diario Ecclesiastico e Civil para as provincias de Pernambuco, Paraiba, Rio Grande do Norte, Ceará e Alagôas, anos de $1841 ; 1843$ e 1847.

Pereira da Costa - Anais Pernambucanos, anos de 1840-1850, MS in Biblioteca Pública do Estado.

Idem - Dicionário de Pernambucanos Célebres.

F. P. de Amaral - Excavações - Factos da Historia de Pernambuco, Pernambuco, Typographia do Jornal do Recife, 1884.

Oliveira Lima - Pernambuco, seu Desenvolvimento Historico, Leipzig, 1895.

Timandro, $O$ Libello do Povo in Revista do Brasil, $\mathrm{n} .^{\circ} 19$, de janeiro, 1940 .

João de Lyra Tavares - Estudo sobre a Rebellião Praieira, Parayba, 1911.

Alfredo de Carvalho - Estudos Pernambucanos, Recife, 1907.

Idem - Phrases e Palavras, Problemas Históricos-Etymologicos, Recife, 1906.

Idem - Annaes da Imprensa Periodica Pernambucana de 1821-1908, Recife, 1908.

Capistrano de Abreu - Ensaios e Estudos (Crítica e História), 1a., 2a. e 3a. séries.

Liberato Bittencourt - Homens do: Brasil, vol. II, Parahyba (Parahybanos Illustres), Rio, 1914.

George Gardner - Viagens ao Brasil, São Paulo, 1942.

William Hadfield - El Brasil, el Rio de la Plata y el Paraguay vistos por un viajero en 1852, Editorial Difusam, Buenos Aires, 1943.

Daniel P. Kidder - Reminiscências de Viagens e Permanência no Brasil (Provincias do Norte), São Paulo.

Charles B. Mansfield - Impressões de Pernambuco, in Rev. do Inst. Arq. Hist. e Geo. Pernambucano, vol. XII, ns. 107 a 110.

Rocha Pombo - Historia do Brasil, vol. VIII.

Pe. Raphael Galanti S. J. - Historia do Brasil, tomo IV.

Diário fntimo do Engenheiro Vauthier, 1840-1846, Prefácio e Notas de Gilberto Freyre, 1940 .

Moreira de Azevedo - A Revolta de 1848 em Pernambuco, in Rev. do Inst. Hist. e Geo. Pernambuco, vol. 27, n. 127.

Sebastião de Vasconcellos Galvão - Diccionario Chrographico Historico e Estatistico de Pernambuco, Rio, 1927.

Gilberto Freyre - Casa Grande \& Senzala, Rio, 1934.

Idem - Sobrados e Mocambos, São Paulo, 1936.

Idem - Nordeste, Rio, 1937.

Idem - Um Engenheiro Francês no Brasil, Rio, 1940.

Idem - Interpretación del Brasil, México, 1945.

Clovis Bevilaqua - História da Faculdade de Direito do Recife, 2 vols., Rio, 1927.

Olivio Montenegro - Memórias do Ginásio Pernambucano, Recife, 1934.

Amaro Quintas - A Gênese do Espírito Republicano em Pernambuco e a Revolução de 1817, Recife, 1939.

Alberto Rangel - No Rolar do Tempo..., Rio.

Idem - Textos e Pretextos, Rio. 
Nelson Werneck Sodré - Formação da Sociedade Brasileira, Rio, 1936 .

Sergio Buarque de Hollanda - Raizes do Brasil, Rio, 1936.

Hélio Vianna - Contribuição a História da Imprensa Brasileira (1812-1869), Rio, 1945.

Idem - Visconde de Sepetiba, Petrópolis, 1943.

Caio Prado Júnior - Evolução Política do Brasil (Ensaio de interpretação materialista da historia brasileira), São Paulo, 1933.

Fernando de Azevedo - A Cultura Brasileira, 2a. Edição, São Paulo, 1941.

Felix Cavalcanti de Mello - Memórias de um Cavalcanti, Introdução de Gilberto Freyre, São: Paulo, 1940.

João Peretti - Aspectos de uma Rebelião, in Jornal do Comércio, Recife, 1945.

Rio Branco - Efemérides Brasileiras, Rio, 1938.

Livros de Correspondência dos Cónsules (Col. da Biblioteca Pública do Estado de Pernambuco).

Anais do Parlamento Brasileiro.

Anais da Assembléia Provincial de Pernambuco.

Jornais consultados, quer na Biblioteca Pública do Estado, quer no Instituto Arqueológico, Histórico e Geográfico Pernambucano: Diario de Pernambuco, Diario Novo, O Lidador, A União, A Voz do Brasil, o Athleta, O Cometa, O Foguete, O Joâo Pobre, A Marmota, A Gazeta do Povo, o Arara, O Praieiro, O Azzorague, O Bezerro de Pera, O Echo da Religiấo e do Imperio, o Grito da Patria, A Reforma, o Guarda Nacional, O Progresso (Revista), o Postilhão, O Sete de Setembro, O Eco Pernambucano, A Carranca, O Novo Mesquita de Capote, O Homem do Povo, O Votante de S. José, o Proletário, O Artista, A Ratoeira, A Tempestade, Hum dos Cinco Mil, O Saquarema, O Indigena, O Liberal, A Barca de S. Pedro, o Brasileiro, A Forquilha, A Ordem, Correio do Norte, O Bom Senso, O Camarão, A Mentira, A Sentinela da Liberdade, o Ecletico, O Advogado do Povo, A Verdade, O Carapuceiro, o Maccabeo, O Liberal Pernambucano, A Revolução de Novembro, O Guararapes, O Repúblico (1885) do Rio, etc.

Consultamos também vários MSS. no Ins. Arq. Hist. e Geo. Pernambucano e no Arquivo Público do Estado. 